\title{
Een meting van de produktiviteit van het Nederlandse bedrijfswetenschappelijke onderzoek in 1990 - 1993
}

Citation for published version (APA):

van Witteloostuijn, A., \& Boone, C. A. J. J. (1996). Een meting van de produktiviteit van het Nederlandse bedrijfswetenschappelijke onderzoek in 1990 - 1993. NIBOR, Netherlands Institute of Business Organization and Strategy Research. NIBOR Research Memorandum No. 01 https://doi.org/10.26481/umanib.1996001

Document status and date:

Published: 01/01/1996

DOI:

10.26481/umanib.1996001

Document Version:

Publisher's PDF, also known as Version of record

\section{Please check the document version of this publication:}

- A submitted manuscript is the version of the article upon submission and before peer-review. There can be important differences between the submitted version and the official published version of record.

People interested in the research are advised to contact the author for the final version of the publication, or visit the DOI to the publisher's website.

- The final author version and the galley proof are versions of the publication after peer review.

- The final published version features the final layout of the paper including the volume, issue and page numbers.

Link to publication

\footnotetext{
General rights rights.

- You may freely distribute the URL identifying the publication in the public portal. please follow below link for the End User Agreement:

www.umlib.nl/taverne-license

Take down policy

If you believe that this document breaches copyright please contact us at:

repository@maastrichtuniversity.nl

providing details and we will investigate your claim.
}

Copyright and moral rights for the publications made accessible in the public portal are retained by the authors and/or other copyright owners and it is a condition of accessing publications that users recognise and abide by the legal requirements associated with these

- Users may download and print one copy of any publication from the public portal for the purpose of private study or research.

- You may not further distribute the material or use it for any profit-making activity or commercial gain

If the publication is distributed under the terms of Article $25 \mathrm{fa}$ of the Dutch Copyright Act, indicated by the "Taverne" license above, 
Een meting van de produktiviteit van het Nederlandse bedrijfswetenschappelijke onderzoek in 1990-1993: Een vergelijking van faculteiten, subdisciplines en wetenschappers

A. van Witteloostuijn \& C. Boone

NIBOR/RM/96/01

http://www.unimaas.nl/ document/fdewb.htm

J.E.Lit. code: M39

$n i b o r$

Netherlands Institute of

Business Organization

and Strategy Research

University of Maastricht

Faculty of Economics and Business Administration

P.O. Box 616

6200 MD Maastricht

The Netherlands

Phone: ++3143 - 3883805 


\title{
EEN METING VAN DE PRODUKTIVITEIT VAN HET NEDERLANDSE BEDRIJFSWETENSCHAPPELIJKE ONDERZOEK IN 1990-1993
}

\author{
Een vergelijking van faculteiten, subdisciplines en \\ wetenschappers
}

Arjen van WITTELOOSTUIJN en Christophe BOONE*

November 1996

(c) 1996 UM/NIBOR

NIBOR (Netherlands Institute of Business Organization and Strategy Research), Faculteit der Econo- 
mische Wetenschappen en Bedrijfskunde, Universiteit Maastricht, Postbus 616, 6200 MD Maastricht. Wij danken Ilja Godfried en Mariëlle Heijltjes voor hun hulp bij de dataverzameling. 


\section{EEN DEBUUT}

Dit is een bijzonder onderzoekmemorandum: niet vanwege de inhoud, hoewel die ongetwijfeld controversieel zal blijken te zijn, maar omdat het een memorandum is dat het eerste produkt is van een nieuw instituut. Eind 1996 is in Maastricht het Netherlands Institute of Business Organization and Strategy Research (NIBOR) formeel opgericht. De oprichting van dit instituut is een logisch gevolg van de onderzoekprofilering van de Maastrichtse Faculteit der Economische Wetenschappen en Bedrijfskunde, waarbij is gekozen voor drie zwaartepunten - financiering, organisatie en technologie - die zijn samengebracht in de facultaire onderzoekschool METEOR (Maastricht School of the Economics of TEchnology and ORganizations). De inhoud van het voor u liggende memorandum biedt overigens een ex post ondersteuning voor de keuze van de twee eerstgenoemde zwaartepunten.

NIBOR is een institutionele bundeling van de expertise van een groep van onderzoekers op het terrein van de organisatiewetenschappen - met bijdragen vanuit met name de moeder-disciplines econom(etr)ie, psychologie en sociologie - uit de lage landen die de ambitie delen om hoogwaardig wetenschappelijk onderzoek te verrichten. Dit profiel heeft ten minste de drie volgende implicaties.

1. In de eerste plaats richten de activiteiten van NIBOR zich op vraagstukken die zijn gerelateerd aan het interne en externe functioneren van organisaties. De multidisciplinaire NIBOR-expertise heeft met name betrekking op vijf deelterreinen van de organisatiewetenschappen: industriële economie, interne organisatie, strategisch management, verandermanagement en, ter ondersteuning, onderzoekmethodologie. Hierbij wordt aandacht besteed aan een breed scala van onderwerpen, variërend van organisatie-ontwerp en leergedrag tot concurrentiestrategie en marktwerking.

2. In de tweede plaats impliceert het NIBOR-profiel dat de harde kern van het instituut wordt gevormd door onderzoekers die werkzaam zijn aan universitaire instellingen in de Nederlandse provincies Brabant en Limburg plus Vlaanderen. Het merendeel van de betrokkenen is verbonden aan de Universiteit Maastricht, terwijl de andere 'Nederlandstalige zuiderlingen' werkzaam zijn aan de Katholieke Universiteit Brabant, het RijksUniversitair Centrum Antwerpen, de Rijksuniversiteit Gent en de Vrije Universiteit Brussel. Daarnaast is overigens een aantal buitenlandse onderzoekers uit Duitsland en de Verenigde Staten aan NIBOR gelieerd.

3. Het vertrekpunt van alle NIBOR-activiteiten is kwaliteit. Deze kwaliteit wordt gewaarborgd via de nadruk op de wetenschappelijke methode van onderzoek. Hierbij ligt het accent op de toepassing van kwantitatieve methoden en technieken van organisatie-onderzoek. Binnen NIBOR wordt gestreefd naar de gebruikmaking van de econom(etr)ische traditie van analytische modellenbouw en geavanceerde toetsingen in combinatie met de uitgebreide ervaring in de gedragswetenschappen met primaire dataverzameling via bij voorbeeld vraaggesprekken en vragenlijsten. In alle gevallen staat een gedegen onderzoekontwerp voorop.

De NIBOR-activiteiten beperken zich niet tot de uitvoering en publicatie van fundamenteel-wetenschappelijk onderzoek - integendeel. Op het solide fundament van de interne fundamenteel-wetenschappelijke expertise, in synergie met een uitgebreid netwerk van externe contacten, wordt het NIBOR-potentieel ingezet ten behoeve van contractonderzoek en -onderwijs. Een illustratieve selectie van recent afgesloten of nog lopende contractonderzoekingen is het volgende vijftal: (1) organisatiecultuur en -prestaties in een middelgrote Nederlandse gemeente; (2) strategie-evaluatie van een Belgisch halfgeleiderlaboratorium; (3) acquisities, allianties en fusies in de (inter)nationale accountancy-, dagbladen-, halfgeleider- en papierindustrieën; (4) de lange-termijnontwikkeling van de Nederlandse dagbladpers; en (5) de effectiviteit van een interventie-programma op de werkvloer van drie Nederlandse voedingfabrieken. Vermel-denswaard is ten slotte dat recentelijk een NWO/PIONIER-voorstel (aanvrager: prof. dr. G.A. Pfann) is goedgekeurd dat nauw aansluit bij het onderzoekprofiel van NIBOR via de gekozen thematiek (investeren door bedrijven; zie profielkenmerk 1), de onderzoekgroep (met een groot aantal NIBOR-leden; zie profielkenmerk 2) en de gehanteerde methodologie (de 'informed-observer approach'; zie profielkenmerk 3). 
Arjen van Witteloostuijn

December 1996

Maastricht 


\section{EEN LANGDURIGE MODE}

Vijftien jaar geleden is het hitlijstenvirus overgeslagen van kunst naar wetenschap. Boeken- en muziektop-tienen en -veertigen waren reeds lang ingeburgerd toen in 1980 de binnen korte tijd alom gevreesde A.D.S. de Schuite zijn eerste economentop-40 publiceerde. In 1989 ontdeed hij zich van zijn vermomming met de woorden: "Na tien jaar legt A.D.S. de Schuite de pen neer. Zijn baanbrekende werk op het gebied van het kwantificeren van wetenschappelijke prestaties heeft inmiddels veel navolging gevonden" (Intermediair, 51, 1989: 17). Hij bleek de econometristen Arie Kapteyn (Tilburg) en Tom Wansbeek (Groningen) te zijn. De fakkel - met een wat kleinere vlam: een economentop-20 werd vervolgens overgenomen door Petra van Ostende. Wetenschappelijk economenland wacht inmiddels jaarlijks in spanning op het kerstnummer van Intermediair. Ook het economenblad Economisch statistische berichten (ESB) laat zich niet onbetuigd. Op 28 december 1994 publiceerde de ESB zijn veertiende economentop-30.

Een virusziekte kan uiterst besmettelijk zijn. Dat is gebleken. Inmiddels worden ook hitlijsten gepubliceerd van allerlei contribuanten aan allerlei andere disciplines, zoals geschiedenis, psychologie en sociologie (zie bij voorbeeld in de Univers, de KUB-krant, van 22 februari 1995). Het mag dan ook geen verbazing wekken dat ook het Zoetermeerse bastion van onderwijskundige en wetenschappelijke regelgeving niet immuun is gebleken voor de telkwaal. In de vorm van een vijf-jaarlijkse cyclus van universitaire onderzoekvisitaties lijkt de Vereniging van Samenwerkende Nederlandse Universiteiten (VSNU) aan de Zoetermeerse druk te hebben toegegeven: elke discipline wordt periodiek blootgesteld aan de teldrift van een commissie van deskundigen, die in een publiek rapport een onverbiddelijk oordeel velt over de onderzoekproduktiviteit en -kwaliteit van Nederlandse faculteiten (en groepen daarbinnen). De overrompelende inhoud van het Protocol 1994 ten behoeve van het Quality assessment of research: onderzoekbeoordeling (Utrecht: VSNU) spreekt boekdelen. De telleritus is gekomen om te blijven. In wielerjargon: we tellen ons het snot voor de ogen in de hoop onszelf van voren te vinden. Het Noord-Amerikaanse 'publish or perish' wordt langzaam maar zeker in aangepaste vorm - als een vast element - opgenomen in de Nederlandse onderzoekcultuur. Uiteraard willen wij als bedrijfswetenschappers niet achter blijven: het meten van produktievolume en produktiviteit is immers ook - en misschien zelfs vooral - een bedrijfswetenschappelijke activiteit. Misschien, om in wielertermen te blijven spreken, groeit de navolgende telexercitie uit tot een jaarlijks terugkerende klassieker - net zoals de economenwedstrijden in de ESB en Intermediair.

\section{WAAROM?}

Jaar na jaar wekken de hitlijsten de nodige beroering onder economen. Vooral economen die vinden dat zij ten onrechte niet - of te laag - staan genoteerd, dragen keer op keer argumenten aan waarom het anders - of niet - moet. Ook de inhoud van het navolgende kan beter worden begrepen in het licht van de afwezigheid van beide auteurs op de ESB- en Intermediair-hitlijsten. Favoriete kritiekpunten hebben betrekking op de methodiek van de puntentelling en/of de selectie van de meegenomen onderzoekprodukten. De economentop-20 van 1994 heeft bij voorbeeld de vakbroeders Steven Brakman (Groningen) en Charles van Marrewijk (Rotterdam) ertoe gebracht te schrijven dat "[v]an de meeste deelterreinen van de economie ... geen (bijvoorbeeld de internationale economie) of slechts 1 (bijvoorbeeld ontwikkelingseconomie of regionale economie) tijdschrift bij Petra van Ostende [is] opgenomen" (Intermediair, 1995, 3: 5). Vooral de bedrijfseconomische tijdschriften schitteren door afwezigheid. Slechts 4 van de 27 Intermediair-tijdschriften richten zich specifiek op de bedrijfseconomie: Journal of Accounting and Economics, Journal of Finance, Journal of Marketing Research en Management Science. Algemene econometristen en (kwantitatieve) economen vinden daarentegen veel van hun gading. 
Op de Intermediair-lijst zijn dan ook weinig bedrijfseconomen - laat staan organisatiepsychologen, sociologen of andere sociale bedrijfswetenschappers - terug te vinden. Met enige goede wil zijn van de 1994-editie hooguit Boot en Nijman bedrijfseconomen te noemen, aangezien deze twee wetenschappers werkzaam zijn in een bedrijfseconomische subdiscipline (financiering; Nijman heeft overigens ook een halftijdbenoeming bij econometrie) - een bijzonder magere score. Dat kan twee dingen betekenen: bedrijfseconomen en -wetenschappers publiceren minder dan hun 'algemene' vakbroeders en/of zij zoeken hun heil in andere internationale tijdschriften. De derde verklaring - in Nederland zijn weinig bedrijfswetenschappers werkzaam - laten we hierbij gemakshalve voor wat het is. De tellingen waarvan op de navolgende bladzijden verslag wordt gedaan, maken het hopelijk mogelijk de validiteit van beide verklaringen te evalueren.

\section{DATAVERZAMELING EN -VERWERKING}

Een uitputtend onderzoek naar het produktievolume en de produktiviteit van alle (groepen van) Nederlandse bedrijfswetenschappers via publicaties in alle media zou met recht en letterlijk uitputtend zijn geweest - voor onderzoeker en lezer. Omdat de meester zich in de beperking toont, hebben wij ervoor gekozen het aantal (groepen van) bedrijfswetenschappers en publicatiemedia te beperken. De eerste beperking is wellicht de belangrijkste: om het Nederlandse bedrijfswetenschappelijk onderzoek in kaart te brengen, is een poging ondernomen te achterhalen waar de producenten van internationaal bedrijfswetenschappelijk onderzoek te vinden zijn: waar en door wie wordt in internationale vaktijdschriften gepubliceerd?

Het uitgangspunt voor deze meting is het (voor co-auteurschappen gecorrigeerde) aantal bladzijden (plus vaste voet) dat is gepubliceerd in de jaren 1990-1993 in tijdschriften die worden meegenomen in de tellingen van de 'Social Science Citation Index' (verder met het 'ongewogen puntenaantal' aangegeven). Om enigszins rekening te houden met de kwaliteit van de publicaties is ook een puntenaantal berekend op basis van de status van de betrokken tijdschriften [in het navolgende het 'gewogen puntenaantal' genoemd]. In navolging van de jaarlijkse Intermediair-top-20 is de volgende formule gehanteerd:

$\mathrm{S}=(2 /(\mathrm{N}+1))(\mathrm{B}+5) \mathrm{W}$,

$\mathrm{S}$ is de score, $\mathrm{N}$ het aantal auteurs en $\mathrm{B}$ het aantal bladzijden per publicatie, terwijl $\mathrm{W}$ een coëfficient is waarmee de kwaliteit van de publicatie wordt aangegeven. Via ' $\mathrm{N}+1$ ' wordt voor co-auteurschappen gecorrigeerd. 'B+5' impliceert een vaste honorering van 5 punten voor elke publicatie, ongeacht de omvang. Drie vragen moeten worden beantwoord voordat de tellingen kunnen beginnen: (i) welke auteurs worden meegenomen?; (ii) welke publicaties worden meegeteld?; en (iii) hoe worden de publicaties gewogen?

De auteurs zijn geselecteerd via twee stappen. Allereerst is gebruik gemaakt van de studiegidsen 1994-1995 en de wetenschappelijke jaarverslagen over 1993 van de betrokken faculteiten. Hierbij zijn drie selectiecriteria gehanteerd. Medewerkers zijn alleen meegenomen indien zij (i) gepromoveerd zijn, (ii) cursussen verzorgen of onderzoek doen op het terrein van één van het viertal bedrijfswetenschappelijke subdisciplines berichtgeving, financiering, marketing en organisatie (zie paragraaf 5) en (iii) geen hoofdaanstelling hebben aan een buitenlandse instelling. De tellingen zijn in eerste instantie beperkt tot de economische faculteiten van de Erasmus Universiteit Rotterdam, Katholieke Universiteit Brabant, Rijksuniversiteit Groningen, Universiteit van Amsterdam en Vrije Universiteit, de economische en bedrijfskundige faculteit van de Rijksuniversiteit Limburg, en de bedrijfskundige faculteiten van Groningen en Rotterdam. Van deze faculteiten zijn - hopelijk - alle medewerkers meegenomen die aan voornoemde criteria voldoen (lijst A met 227 gepromoveerde bedrijfswetenschappers). Daarnaast werd een 
additionele lijst samengesteld (lijst B) waarin een drietal categorieën bedrijfswetenschappers, die niet in lijst A voorkomen, is opgenomen: (1) 18 onderzoekers die in de top-40 van Van Heerde \& Leeflang (1995) figureren, maar niet in lijst A (zie paragraaf 7.10); (2) 19 bekende bedrijfswetenschappers die werkzaam zijn aan Vlaamse universiteiten (zie paragraaf 7.7); en (3) 53 gepromoveerde bedrijfswetenschappers die niet in lijst A zijn terug te vinden, maar wel actief zijn in de Nederlandse kring van organisatie-onderzoekers [binnen bij voorbeeld de Nederlands-Vlaamse Academie voor Management (NVAM); zie paragraaf 7.5]. Deze toevoegingen impliceren dat ook (i) de bedrijfswetenschappelijke subdisciplines informatie en logistiek (zie paragraaf 5), (ii) de faculteiten der technische bedrijfskunde van Eindhoven en Twente, (iii) bedrijfswetenschappers werkzaam aan niet-bedrijfskundige en nieteconomische instellingen en (iv) produktieve emeritushoogleraren (bij voorbeeld Hofstede en Lammers) zijn vertegenwoordigd in de tellingen. In appendix I is de volledige lijst met namen opgenomen (lijst $A$ en $B)$, inclusief additionele informatie en een verantwoording.

De publicaties betreffen de tijdschriften die zijn opgenomen in de 'Social Science Citation Index' (SSCI). De SSCl is vermoedelijk de minst omstreden bron voor een sociaal-wetenschappelijke tijdschriftenlijst: in tegenstelling tot de VSNU-lijst zijn de SSCI-tijdschriften geselecteerd, en de bijbehorende wegingen vastgesteld, zonder de tussenkomst van belanghebbenden - in casu: de Nederlandse (bedrijfs)wetenschappers zelf. De weging van tijdschriften is gebaseerd op de vuistregel voor de driedeling van tijdschriften - op basis van de 'impact score' (I) van 1991 - die de recente visitatiecommissie psychologie heeft gehanteerd (Psychological Research in the Netherlands: Past Performance and Future Perspectives, April 1994, Utrecht: VSNU, 7-8): $\mathrm{W}=1$ indien I $\leq 0,4 ; \mathrm{W}=2$ indien $0,4<\mathrm{I} \leq$ 0,9 ; en $\mathrm{W}=3$ indien I > 0,9. De 'impact score' $\mathrm{I}$ is een maatstaf voor het belang van een tijdschrift aan de hand van de frequentie waarin een 'gemiddeld' artikel gepubliceerd in het betreffende tijdschrift wordt geciteerd. In de Verenigde Staten wordt veelvuldig gebruik gemaakt van de SSCI (Laband \& Piette, 1994). De hier gehanteerde driedeling is enigszins te vergelijken met de VSNU-classificatie in A-, B- en C-tijdschriften. Een groot verschil is echter dat de VSNU-lijst is gebaseerd op de beoordeling van de betrokkenen - een selectie van Nederlandse econom(etrist)en -, terwijl onze indeling gebruik maakt van een objectieve bron. Een discrete classificatie is overigens te prefereren boven een continue weging (op basis van de 'impact scores', die tot vier decimalen nauwkeurig worden geregistreerd) om ten minste twee redenen (zie paragraaf 7.9): (i) de verschillen in de 'impact scores' van tijdschriften kunnen niet worden geïnterpreteerd als een nauwkeurige reflectie van absolute verschillen in kwaliteit - anders zou bij voorbeeld moeten worden aangenomen dat The Economist (met een 'impact score' van 7,308) bijna vijf maal 'beter' is dan de American Economic Review $(1,588)$; en (ii) een continue weging is nogal gevoelig voor verschuivingen in de waarden van de 'impact scores', hetgeen zou impliceren dat de kwaliteit van tijdschriften fors kan schommelen binnen een tijdbestek van een paar jaren. In appendix II zijn alle tijdschriften opgenomen waarin ten minste één maal is gepubliceerd door een bedrijfswetenschapper van lijst A en B (appendix I) in de periode 1990-1993. Overigens zijn drie typen SSCIpublicaties niet meegeteld - '(special issue) editorials', '(meeting) abstracts' en '(book) reviews' - en hebben we ons beperkt tot 'echte' artikelen.

\section{TEN MINSTE ZEVEN FOUTEN}

Een onderzoek als het onderhavige kan niet anders dan vol fouten zitten. Gezien het 'gevoelige' misschien zelfs explosieve - karakter van hitlijsten, kan het geen kwaad hieraan een paragraaf te wijden. 'Slachtoffers' kunnen dan moeiteloos deze voorzet inkoppen - om bij wijze van afwisseling een voetbalmetafoor te gebruiken. Zonder de pretentie uitputtend te zijn, is de volgende opsomming van zeven (niet alleen het goede komt in zevenvoud) 'standaard'fouten illustratief.

(1) Fout I: telfout. Niet iedereen is in staat foutloos te tellen. Hier en daar kan een pagina vergeten 
zijn, een co-auteur over het hoofd zijn gezien, een artikel zijn vergeten, een weging niet deugen of een optelling te laag zijn uitgevallen (en, in andere gevallen, vice versa - maar vermoedelijk komt ons dat niet ter ore). Daarnaast is het de vraag hoe moet worden omgesprongen met publicaties die (ver) buiten de subdisciplines vallen.

(2) Fout II: auteurfout. Ongetwijfeld is de lijst met auteurs (appendix I) te kort en te lang: te kort, omdat menigeen ontbreekt; te lang, omdat een enkeling toch niet aan de criteria voldoet. Erger nog: de criteria zijn voor discussie vatbaar. Waarom zijn deeltijdmedewerkers met een hoofdaanstelling in het buitenland niet opgenomen? Waarom zijn produktieve ongepromoveerden genegeerd? Waarom zijn bedrijfswetenschappers die buiten de universitaire wereld opereren, buiten schot gebleven?

(3) Fout III: mediafout. Ten onrechte is alleen in de SSCI geturfd. Daarin blijven immers veel internationale tijdschriften ongenoemd. Belangrijker nog: waarom zijn nationale tijdschriftartikelen, (hoofdstukken in) boeken, congrespresentaties, onderzoekmemoranda, boekrecensies, adviesverslagen, krantecolumns en radio- en televisiecommentaren moedwillig buiten de tellingen gehouden?

(4) Fout IV: wegingfout. Tijdschriften krijgen een te laag of te hoog gewicht, en de indeling in drie categorieën (inclusief de hieraan gekoppelde gewichten) is (zijn) arbitrair en ondeugdelijk. Nog een stap verder: net als de beruchte VSNU-lijst met A-, B-, C-, D- en E-tijdschriften, deugt ook de SSCl-'impact score' niet.

(5) Fout V: tijdfout. De metingen zijn slechts een momentopname. Allerlei talenten zijn na 1993 doorgebroken, enkele gevestigde bedrijfwetenschappers hebben in 1990-1993 toevallig magere jaren doorgemaakt en een groot aantal nieuwe tijdschriften is inmiddels tot het SSCI-Walhalla toegetreden.

(6) Fout VI: generalisatiefout. De ene subdiscipline is de andere niet. Met het vergelijken van subdisciplines wordt gesuggereerd dat appels, druiven, frambozen en peren - omdat het allemaal fruit is - over één kam kunnen worden geschoren. Niets is minder waar. De publicatiecultuur in berichtgeving wijkt bij voorbeeld volledig af van die in financiering.

(7) Fout VII: denkfout. Het meten - en dus kwantificeren - van de kwaliteit van onderzoek is onmogelijk. Daarom zijn de navolgende tellingen en vergelijkingen zinloos, en zelfs misleidend. Eén klassieke publicatie is duizend keer meer waard dan honderd nooit geciteerde artikelen. Misschien dat daarom een citatentelling wat meer hout zou snijden (zie voor een fraaie poging Van Dalen, 1995), hoewel ook dat het meten van het onmeetbare impliceert. De Noord-Amerikaanse 'publish-and-perish'mentaliteit is misplaatst en verwerpelijk, zeker in Nederland.

Graag roepen wij lezers op om ons op onze fouten te wijzen, zodat met recht kan gelden: een volgende keer beter (fout VII uitgezonderd). Bij wijze van voorproefje is in box 1 de brief gereproduceerd die wij hebben mogen ontvangen van een lezer met voorinformatie.

\section{BOX 1 INVOEGEN}

\section{FACULTEITEN}

De bedrijfswetenschappen bestaan uit een verzameling van (sub)disciplines die zich richten op de bestudering van het functioneren van organisaties in het algemeen en bedrijven in het bijzonder (Van Witteloostuijn, 1995). Het kan geen kwaad kort stil te staan bij de nogal verwarrende semantiek: de subdiscipline organisatie is onderdeel van de veel bredere bedrijfswetenschappen - in de vorm van met name de bedrijfseconomie en de bedrijfskunde; naast organisatie als 'kernvak' binnen de bedrijfseconomische en bedrijfskundige curricula bestaat organisatiesociologie als zelfstandige discipline; het 
verschil tussen bedrijfseconomie en bedrijfskunde is aan menige buitenlandse vakgenoot moeilijk duidelijk te maken; et cetera. Deze naamgevingen zijn historisch gegroeid: veel bedrijfseconomie en bedrijfskunde gaat ook over niet-winstgeoriënteerde organisaties; veel organisatiekundig onderzoek is vooral geënt op het functioneren van winstgerichte bedrijven. Om die reden is de onderverdeling in homogene(re) subdisciplines aanmerkelijk beter werkbaar.

Ruwweg is in de loop der tijd een zestal bedrijfswetenschappelijke subdisciplines ontstaan: (1) berichtgeving; (2) financiering; (3) informatie; (4) logistiek; (5) marketing; en (6) organisatie. Natuurlijk is de grens tussen de zes subdisciplines lang niet altijd even duidelijk te trekken. Twee voorbeelden kunnen dit illustreren. Ten eerste nemen onderdelen van het strategisch management - met name de concurrentie-analyse - een belangrijke plaats in binnen zowel marketing als organisatie. Ten tweede heeft een benadering als de agentschapstheorie ingang gevonden in vooral de berichtgeving, financiering en organisatie. Mede ten gevolge van de separate institutionalisering van de subdisciplines nationaal en internationaal - is het aantal concrete samenwerkingen tussen vertegenwoordigers van verschillende deelterreinen tot dusverre echter uiterst beperkt gebleven.

Het lijkt wel alsof de Nederlandse bedrijfwetenschappers zich hebben verspreid over een zo groot mogelijk aantal universitaire instellingen. De vijf (zes) bedrijfskundige en vijf (zes) economische faculteiten zijn nog duidelijk herkenbaar: de bedrijfskundige faculteiten van de Erasmus Universiteit Rotterdam, Rijksuniversiteit Groningen, Nijenrode, Technische Universiteit Eindhoven en Technische Universiteit Twente, de economische faculteiten van de Erasmus Universiteit Rotterdam, Katholieke Universiteit Brabant, Rijksuniversiteit Groningen, Universiteit van Amsterdam en Vrije Universiteit, en tot slot de economische en bedrijfskundige faculteit van de Rijksuniversiteit Limburg. Dat is anders gesteld met de organisatiesociologische groepen binnen de sociale faculteiten en hun borelingen (zoals beleidswetenschappen, bestuurskunde, communicatiewetenschap en personeelswetenschappen). In veel van deze faculteiten zijn ook bedrijfswetenschappers - met name werkzaam op de deelterreinen van de subdiscipline organisatie - te vinden.

Om een vergelijking van de produktie en produktiviteit van faculteiten 'zuiver' te houden is ervoor gekozen de 'geaggregeerde' analyse te beperken tot de bedrijfskundige faculteiten van de Erasmus Universiteit Rotterdam en de Rijksuniversiteit Groningen, de economische faculteiten van de Erasmus Universiteit Rotterdam, Katholieke Universiteit Brabant, Rijksuniversiteit Groningen, Universiteit van Amsterdam en Vrije Universiteit, en tot slot de economische en bedrijfskundige faculteit van de Rijksuniversiteit Limburg (lijst A in appendix I; zie paragraaf 6 voor een opmerking hierover). Deze acht instellingen zijn geselecteerd op grond van twee argumenten. In de eerste plaats opereren deze instellingen alle in dezelfde institutionele context: het zijn van rijkswege gefinancierde publieke universiteiten met erkende eerste-fase drs- en tweede-fase dr-opleidingen in de bedrijfskunde en/of bedrijfseconomie - in tegenstelling tot het private Nijenrode. In de tweede plaats leggen zij alle een vergelijkbaar accent op de 'algemene' (dat wil zeggen: niet-technische) bedrijfswetenschappelijke subdisciplines: berichtgeving, financiering, marketing en organisatie - in tegenstelling tot de 'technische' opleidingen in Eindhoven en Twente. De navolgende tellingen hebben dan ook betrekking op deze vier bedrijfswetenschappelijke subdisciplines (zie hierover paragraaf 6 en appendix III). Een selectie van andere bedrijfswetenschappers - onder wie ook onderzoekers die werkzaam zijn aan andere dan bedrijfskundige of economische faculteiten - wordt overigens in paragraaf 7 in de analyses betrokken.

De geaggregeerde resultaten - per faculteit - van de tellingen zijn terug te vinden in tabel 1. Merk op dat in deze en navolgende tabellen geen enkele van de (on)gewogen puntenscores $(P, B, P / G$ en $B / G$ ) is vervuild ten gevolge van dubbeltellingen (zie paragraaf 3 ). Dit geldt niet voor de recht-toe-rechtaan telling van het aantal gepubliceerde artikelen (A; zie appendix II).

\section{TABEL 1 INVOEGEN}

In het algemeen is sprake van een magere produktie en produktiviteit: 225 gepromoveerde stafleden 
leverden 135 bijdragen aan internationale tijdschriftartikelen - met een gemiddelde van 0,6 per gepromoveerde bedrijfswetenschapper over vier jaar (dus: 0,15 per jaar). De uitzonderingen bevestigen de regel. Vooral de economische faculteiten van de Rijksuniversiteit Limburg en de Universiteit van Amsterdam springen in het oog met 18,5 ongewogen en 33,3 gewogen respectievelijk 15,9 ongewogen en 27,9 gewogen punten per gepromoveerde bedrijfswetenschapper. In negatieve zin vallen met name de Vrije Universiteit (1,5 ongewogen en 3,4 gewogen punten per gepromoveerde bedrijfswetenschapper) en de bedrijfskundige faculteit van de Rijksuniversiteit Groningen (2,7 ongewogen en 3,2 gewogen punten per gepromoveerde medewerker) op. Tot slot kan nog worden gewezen op de verschillen tussen de bedrijfskundige en economische faculteiten: in het algemeen is zowel het produktievolume als de produktiviteit hoger bij de economische faculteiten [278,1 (479,5) versus $168(269)$ ongewogen (gewogen) punten per faculteit respectievelijk 10,6 (18,2) versus $5,1(8,1)$ ongewogen (gewogen) punten per gepromoveerde bedrijfswetenschapper].

\section{SUBDISCIPLINES}

Een tweede analyse vindt plaats op het niveau van vier bedrijfswetenschappelijke subdisciplines: berichtgeving, financiering, marketing en organisatie. Voordat de resultaten van de tellingen worden gepresenteerd, is het nuttig nog twee opmerkingen te maken. In de eerste plaats sluit de organisatiestructuur van de Nederlandse bedrijfskundige en economische faculteiten veelal nauw aan op deze vierdeling in subdisciplines. Bijna altijd zijn vakgroepen/secties terug te vinden met vergelijkbare benamingen. Hierbij moet echter de kanttekening worden gemaakt dat de vierde subdiscipline - organisatie in veel gevallen het karakter van een grabbelton lijkt te hebben gekregen (zie Van Witteloostuijn, 1995): de reeks industriële economie, innovatiemanagement, personeelsmanagement, organisatiegedrag, produktiemanagement en strategisch management biedt maar een zestal voorbeelden van deelterreinen die vaak - maar lang niet altijd - onder de noemer van organisatie zijn samengebracht. Het karakter van de drie (vijf) andere subdisciplines - berichtgeving, financiering en marketing (en ook informatie en logistiek) - is aanmerkelijk homogener. In appendix III wordt aangegeven welke vakgroepen/secties - en daarmee hun gepromoveerde medewerkers - in de tellingen zijn meegenomen, en waarom.

In de tweede plaats verdient de rol van de 'moederdisciplines' - vooral economie, psychologie en sociologie - nadere toelichting. Zowel de studie van het externe functioneren als de analyse van het interne functioneren van organisaties heeft een interdisciplinair karakter. Bij voorbeeld de analyse van financiële markten en het marktonderzoek naar afnemers kunnen niet voorbij gaan aan de (massa)psychologie van de betrokkenen en de invloed van algemeen-economische variabelen. Het strategisch management is een ander duidelijk voorbeeld: de primaire taak van het strategisch management is het analyseren van de omgeving en de positionering van de organisatie binnen het veld van (concurrentie)krachten. Hierbij kunnen bijdragen van onder meer de economie (de werking van concurrentie), maar ook die van de politicologie (de gedragingen van overheden) en het recht (de beschrijving van wetgeving) niet worden gemist. Het combineren van inzichten uit diverse disciplines is eveneens van groot belang bij de bestudering van de interne organisatie. In dit verband is de rol van de arbeids- en organisatiepsychologie enerzijds en organisatiesociologie anderzijds opvallend. Vanwege het multidisciplinaire karakter van vooral de subdiscipline organisatie is een aantal prominente organisatiepsychologen en -sociologen (zie lijst B in appendix I) opgenomen in de tellingen ten behoeve van de meting van de individuele produktie van bedrijfswetenschappers (zie paragraaf 7.5).

In tabel 2 staan proxies van het produktievolume en de produktiviteit van de geselecteerde vier subdisciplines weergegeven voor de acht bedrijfskundige en economische faculteiten (zie weer lijst $A$ in appendix I).

TABEL 2 INVOEGEN 
Merk op dat een aantal prominente bedrijfswetenschappers niet in de tellingen ten behoeve van tabel 2 (en 1) is meegenomen ten gevolge van de uiteenlopende peildata van de publicaties enerzijds (SSCl van 1990-1993) en de publicisten anderzijds (studiegids 1994/1995 en wetenschappelijke jaarverslagen over 1993). Het voorbeeld van de Maastrichtse organisatiegroep is illustratief: hoewel in de periode 1990-1993 de vooraanstaande hoogleraren Hofstede en Sorge aan deze groep (vrijwel) voltijds waren verbonden, ontbreken zij in lijst A - en dus in de tellingen van de tabellen 1 en 2 - vanwege hun 'status' in 1994 (Sorge was toen inmiddels met een hoofdaanstelling aan de Humboldt Universität Berlin verbonden, terwijl Hofstede net met emeritaat was gegaan). Omdat wij zelden op de hoogte zijn van dit soort mutaties binnen andere instellingen, hebben wij de peildatum van - meestal - 1994 gehandhaafd.

Op basis van de cijfers in tabel 2 kan een vijftal voorlopige deelconclusies worden getrokken (in willekeurige volgorde).

(1) In de eerste plaats is de magere prestatie van berichtgeving opvallend: op een spaarzame uitzondering na - één Limburgs en één Rotterdams internationaal tijdschriftartikel in 1990-1993 - lijken de Nederlandse onderzoekgroepen in de berichtgeving zich volledig te richten op de nationale onderzoekmarkt. Hetzelfde geldt, zij het in mindere mate, voor marketing: slechts de onderzoekgroepen van de Rotterdamse bedrijfskundige en Groningse economische faculteiten zijn redelijk actief op de internationale onderzoekmarkt (met 153,5 ongewogen en 313,5 gewogen respectievelijk 84,9 ongewogen en 131,7 gewogen punten, in beide gevallen - toevallig - via 9 artikelen in internationale tijdschriften met 8 gepromoveerde stafleden).

(2) In de tweede plaats zijn vooral binnen de subdiscipline financiering het produktievolume en produktiviteit hoog: 844,6 ongewogen en 1544,8 gewogen punten via 54 internationale tijdschriftartikelen met 47 gepromoveerde bedrijfswetenschappers (in vergelijking met 828,3 respectievelijk 1297,0 van de op één-na-produktiefste subdiscipline - organisatie - via 56 internationale tijdschriftartikelen met 103 gepromoveerde bedrijfswetenschappers).

(3) In de derde plaats doet een vifftal onderzoekgroepen het opvallend goed: financiering aan de Katholieke Universiteit Brabant (25,1 ongewogen en 47,7 gewogen punten per gepromoveerde medewerker), Rijksuniversiteit Groningen (20,8 ongewogen en 32,3 gewogen punten per gepromoveerde medewerker), Rijksuniversiteit Limburg (21,8 ongewogen en 44,1 gewogen punten per gepromoveerde medewerker) en Universiteit van Amsterdam (38,8 ongewogen en 73,3 gewogen punten per gepromoveerde medewerker) en organisatie aan de Rijksuniversiteit Limburg $(31,1$ ongewogen en 53,7 gewogen punten per gepromoveerde medewerker). In absolute termen hebben financiering van de Universiteit van Amsterdam (271,8 ongewogen en 513,1 gewogen punten via 13 artikelen) en organisatie van de Rijksuniversiteit Limburg (342,0 ongewogen en 590,2 gewogen punten via 24 artikelen) veruit het hoogste produktiecijfer.

(4) In de vierde plaats heeft een fors aantal onderzoekgroepen - 12 van de 32 (37,5\%), met een totaal van 44 gepromoveerde stafleden - geen enkel artikel in een internationaal tijdschrift gepubliceerd. Daarnaast hebben 7 onderzoekgroepen slechts één of twee internationale tijdschriftartikelen geproduceerd.

(5) De beide bedrijfskundige faculteiten besteden nauwelijks aandacht aan beide financieel-economische subdisciplines, berichtgeving en financiering, terwijl alle economische faculteiten met uitzondering van die van de Vrije Universiteit juist een accent lijken te leggen op financiering. De subdiscipline organisatie is alom sterk vertegenwoordigd, maar dat heeft vermoedelijk alles te maken met haar 'grabbelton'karakter.

\section{WETENSCHAPPERS}

\subsection{Individuele produktie}

Uiteindelijk is het merendeel van de (bedrijfs)wetenschappers vermoedelijk vooral geïnteresseerd in de 
individuele produktie van zichzelf en hun concullegae. Niets menselijks is wetenschappers immers vreemd. In het navolgende wordt, om in deze behoefte te voorzien, een groot aantal hitlijsten geproduceerd - per subdiscipline en voor de subdisciplines tezamen. Behalve wanneer anders vermeld, hebben de lijsten betrekking op de gepromoveerde bedrijfswetenschappers die werkzaam zijn bij één van de acht geselecteerde faculteiten (zie de tabellen 1 en 2, en lijst A in appendix I) Bij wijze van voorzet worden naar aanleiding van elke hitlijst enkele summiere bespiegelingen geformuleerd. Het is aan een ieder om andere en/of verdere conclusies te trekken.

\subsection{Berichtgeving: slechts een top-2}

Binnen de subdiscipline berichtgeving wordt nauwelijks internationaal gepubliceerd: slechts twee van de 34 gepromoveerde 'berichtgevers' hebben in 1990-1993 een artikel in een SSCI-tijdschrift gepubliceerd: Buijink (RL) en Van der Tas (EUR/FB). Binnen berichtgeving is daarom sprake van een top-3, met alle 31 andere 'berichtgevers' ex aequo op positie 3: voor iedereen ten minste een bronzen medaille! In tabel 3 staat de top-2 vermeld.

\section{TABEL 3 INVOEGEN}

Een voor de hand liggende verklaring voor de magere produktie binnen berichtgeving is te vinden in de nationale oriëntatie van het vak - met een dominante nationale regelgeving - en zijn beoefenaren. Hierbij kan nog de kanttekening worden geplaatst dat grote aantallen academische 'berichtgevers' (i) niet zijn gepromoveerd en/of (ii) hun hoofdaanstelling in de praktijk hebben. Frappant is bij voorbeeld dat nogal wat hooglereren buiten het bestand zijn gebleven ten gevolge van hun ongepromoveerde status. Binnen de berichtgeving is het - althans in Nederland - van oudsher gebruikelijk om de nadruk te leggen, in onderwijs en onderzoek, op de binding met de (Nederlandse) praktijk.

\subsection{Financiering: de kwantitatieve school}

Binnen de subdiscipline financiering is een brede top actief: een fors aantal onderzoekers heeft in 19901993 regelmatig in internationale tijdschriften gepubliceerd. Dertien 'financierders' hebben ten minste twee artikelen het licht doen zien in een SSCI-tijdschrift, terwijl daarnaast nog vijf publicisten één SSCIartikel in druk hebben laten verschijnen (van de 47 gepromoveerde 'financierders'). In tabel 4 is de 'ongewogen' top-15 gereproduceerd, en in tabel 5 de 'gewogen' hitlijst.

\section{TABEL 4 EN 5 INVOEGEN}

Op grond van beide hitlijsten kan een drietal conclusies worden getrokken. Allereerst is de ranglijst nauwelijks gevoelig voor de weging van tijdschriften: de introductie van een gedifferentieerde weging leidt slechts tot marginale verschuivingen in de relatieve posities. Daarnaast is het opvallend dat de 'toppers' over heel Nederland verspreid hun werk doen: Amsterdam (Boot, Zou en Perotti), Groningen (Dijkstra, Sterken en Van Loon), Maastricht (Koedijk, Schotman en Wolff), Rotterdam (Kofman, Van de Sar, Spronk en Vorst) en Tilburg (Nijman en Bossaerts) hebben alle vertegenwoordigers in de top- 15 . Hierbij schitteren de niet-economische faculteiten overigens door afwezigheid. Ten slotte is een fors aantal financiële publicisten uiterst actief op de internationale onderzoekmarkt - Nijman, Boot en Koedijk hebben ieder ten minste zes artikelen in SSCl-tijdschriften afgedrukt gekregen. Wat vrijwel alle (alle?) 'financierders' gemeen hebben is het kwantitatieve karakter van het onderzoek. Een wiskundig-analytisch en/of empirisch-econometrisch karakter van een manuscript lijkt een conditio sine qua non voor publicatie in internationale vaktijdschriften.

\subsection{Marketing: een smalle top}

Ondanks het grote aantal wetenschappelijke 'marketeers' (41), is slechts een kleine groep tot de 
publicatietop doorgedrongen. Ook heeft maar een kleine minderheid het gebracht tot een publicatie in een SSCI-tijdschrift in de periode 1990-1993 (12, waarvan slechts 4 meer dan één keer). De 'ongewogen' en 'gewogen' top-12 zijn afgedrukt in tabel 6 respectievelijk 7.

\section{TABEL 6 EN 7 INVOEGEN}

De top is smal: alleen Van Raaij, Krijnen, Wedel en Bamossy hebben in 1990-1993 twee of meer artikelen gepubliceerd in SSCl-tijdschriften, waarbij vooral de produktiviteit van de eerste in het oog springt. De top wordt gevolgd door een klein peleton van auteurs (8) die één keer het SSCl-bastion hebben weten te slechten. Ook hier zijn beide lijsten vrijwel identiek, en is de regionale spreiding van produktieve 'marketeers' evenwichtig, hoewel vooral Groningen en (met name bedrijfskundig) Rotterdam een woordje meespreken. Slechts Tilburg (en gemeentelijk Amsterdam plus bedrijfskundig Groningen) is (zijn) opvallend afwezig.

\subsection{Organisatie: een heterogeen gezelschap}

De subdiscipline organisatie kent veruit het hoogste aantal vertegenwoordigers. Dat heeft alles te maken met het heterogene karakter van dit deel van de bedrijfswetenschappen (zie paragraaf 6). Om deze heterogeneiteit beter tot uitdrukking te laten komen hebben we 49 gepromoveerden aan de oorspronkelijke lijst toegevoegd (zie lijst B in appendix I). Van het totale aantal van 152 Nederlandse organisatiewetenschappers, inclusief een fors aantal organisatiepsychologen en -sociologen, hebben 44 'organisatiedeskundigen' in de periode 1990-1993 in SSCl-tijdschriften gepubliceerd (zie appendix I). De subtop is breed. In tabel 8 (ongewogen puntenaantal) en 9 (gewogen puntenaantal) staat de top-20 vermeld.

\section{TABEL 8 EN 9 INVOEGEN}

Naar aanleiding van beide tellingen is een drietal opmerkingen vermeldenswaard. In de eerste plaats zijn de verschillen tussen de 'ongewogen' en 'gewogen' ranglijsten niet groot. Slechts twee organisatiepsychologen (Koopman en Thierry) moeten het veld ruimen - ten faveure van de bedrijfskundigen Neuijen en Ruigrok - zodra de gewichten van publicaties worden meegenomen. Neuijen profiteert bij voorbeeld van een publicatie (samen met onder andere Hofstede) in het top-vakblad Administrative Science Quarterly (met weging 3). In de tweede plaats is de positie van de Rijksuniversiteit Limburg bijzonder sterk: niet alleen levert deze instelling de top-3 (Van Witteloostuijn, Hofstede en Hagedoorn), maar daarnaast zijn in beide hitlijsten maar liefst acht 'Limburgers' vertegenwoordigd. In de derde plaats illustreren de in totaal 22 namen nogmaals dat de subdiscipline organisatie een allegaartje is. De volgende opsomming (met telkens twee voorbeelden) spreekt boekdelen: industriële (Deneffe en Van Wegberg) en institutionele (Groenewegen en Beije) economen figureren naast bedrijfskundigen (Huygen en Neuijen), organisatiepsychologen (Koopman en Thierry) en strategie-onderzoekers (Romme en Elfring). Deze pluriformiteit verklaart mogelijk ook de breedte van de subtop en de grote variatie in produktiviteit.

\subsection{Twee andere subdisciplines: informatie en logistiek}

Ook informatie en logistiek behoren tot de kern van de bedrijfswetenschappen. Om het mogelijk te maken enig inzicht in de produktiviteit binnen deze twee subdisciplines te verkrijgen is een selecte steekproef van 'informatici' en 'logistici' bij de tellingen betrokken. De steekproef is gebaseerd op de telexercitie van Van Heerde \& Leeflang (1995) en de ledenlijst (van begin 1995) van de NVAM. Drie van de tien publicisten hebben een plaatsje verworven in de SSCI van 1990-1993. Deze top-3 staat vermeld in tabel 10. 
De topproducent is Kleijnen. De anderen volgen op respectabele afstand. Uiteraard is de steekproef van onderzoekers alles behalve aselect. Misschien dat buiten ons bestand bijzonder produktieve 'informatici' of 'logistici' zijn te vinden. Ook is het denkbaar dat veel onderzoekers binnen deze deeldisciplines publiceren via andere media - bij voorbeeld in nationale vakbladen of in tijdschriften die zijn opgenomen in de 'Science Citation Index' (SCI).

\subsection{Een ander cultuurgebied: Vlaanderen}

Is het hiervoor geschetste beeld typisch Nederlands? Bestaat een 'continentale' onderzoektraditie naast een Angelsaksische (Frey \& Eichenberger, 1993)? Deze vragen zijn uiteraard niet eenvoudig te beantwoorden. Menig AiO zou haar/zijn onderzoektanden erop kunnen stuk bijten. Om een begin van een antwoord te vinden hebben we een twintigtal Vlaamse of in Vlaanderen werkzame bedrijfswetenschappers aan de Nederlandse lijst toegevoegd (zie appendix I). Hiervoor is gebruik gemaakt van twee 'criteria': (i) presentie op de ledenlijst (van begin 1995) van de NVAM en/of (ii) internationale reputatie (naar onze persoonlijke taxatie). Ook Vlamingen met een deeltijdaanstelling in Nederland (zoals Sleuwaegen en Vermaelen) zijn meegenomen. Daarnaast is binnen elke subdiscipline naar een aantal vertegenwoordigers gezocht. De 'Vlaamse' top-10 staat weergegeven in tabel 11 ('ongewogen') en 12 ('gewogen').

\section{TABEL 11 EN 12 INVOEGEN}

De 'Vlaamse' top-10 wordt aangevoerd - het is niet anders - door een Nederlander. Hierbij past overigens de kanttekening dat in de 'Nederlandse' lijsten Vlamingen - vermits in Nederland werkzaam kunnen figureren (een voorbeeld daarvan is de Antwerpse forens Boone). Het selecte karakter van de 'Vlaamse' steekproef maakt het moeilijk - zelfs onmogelijk - algemene conclusies te verbinden aan de vergelijking van de 'Vlaamse' top-10 met de 'Nederlandse' hitlijsten. Toch is het aardig om de denkbeeldige positie van de geselecteerde Vlamingen in de Nederlandse hitlijsten te traceren. Steenkamp zou met stip - als nummer 2 - binnenkomen op de '(on)gewogen' marketingtop-12; Sercu zou Koedijk verdringen van de vierde plaats in de 'ongewogen' top-40 van 'financierders', en Perotti van de zevende positie in de 'gewogen' lijst; Moenaert zou zich als nummer 2 nestelen tussen Van Witteloostuijn en Hofstede in de 'ongewogen' organisatietop-20, terwijl de vijfde plaats voor hem zou moeten worden vrijgemaakt in de 'gewogen' lijst; binnen berichtgeving, ten slotte, verandert de top-2 in een top-4, met Jegers op positie $1 / 2$ en Ooghe (nummer 11 in de denkbeeldige 'Vlaamse' top-12) op 3. Kortom: vermoedelijk wijkt het produktievolume van de 'Vlaamse' (sub)top weinig af van die van de 'Nederlandse'.

\subsection{Alle subdisciplines: een vergelijking}

Als klapstuk zijn in tabel 13 en 14 de 'ongewogen' en 'gewogen' top-40 van de Nederlands-Vlaamse bedrijfswetenschappen opgenomen.

\section{TABEL 13 EN 14 INVOEGEN}

Met uitzondering van berichtgeving (alleen de Vlaming Jegers mag zich in een notering in beide hitlijsten verheugen, terwijl Buijink alleen in de 'ongewogen' top-40 figureert) en informatie/logistiek (met alleen een hoge notering van Kleijnen) blazen alle subdisciplines hun partijtje mee. Vooral financiering (12 en 13 vertegenwoordigers in de 'ongewogen' respectievelijk 'gewogen' top-40 - met zelfs de nummers 1 en 2 in de 'gewogen' variant) en organisatie (22 respectievelijk 20 noteringen, inclusief de nummer 1 in de 'ongewogen' lijst) leveren veel produktieve bedrijfswetenschappers. Daarnaast valt op dat de bedrijfs- 
kundige faculteiten (met 62 van de 225 gepromoveerde bedrijfswetenschappers van lijst A - dat is ongeveer $28 \%$ - plus enkele tientallen medewerkers van de technische universiteiten) slechts vier (10\% van de 'ongewogen' lijst) respectievelijk drie (7,5\% van de 'gewogen' top-40) noteringen hebben weten te bemachtigen. Het selecte gezelschap van 'Vlamingen' doet het beduidend beter, met $9(22,5 \%$, inclusief Vermaelen) en 8 (20\%) vertegenwoordigers in de 'ongewogen' respectievelijk 'gewogen' hitlijst. Ten slotte is de positie van de jonge en relatief kleine Maastrichtse faculteit vermeldenswaard: deze instelling levert 10 (25\%) bedrijfswetenschappers voor de 'ongewogen' en $11(27,5 \%)$ voor de 'gewogen' hitlijst, met zelfs vijf vertegenwoordigers in de 'gewogen' top-10. Vooral de positie van de Vrije Universiteit is daarentegen voor verbetering vatbaar [met slechts twee noteringen (nummer 37 en 38) in de 'gewogen' lijst].

Opvallend zijn de grote verschillen in publicatieprofiel (en -strategie?) van individuele bedrijfswetenschappers. In box 2 staan vier illustratieve profielen geschetst, met gebruikmaking van twee dimensies: (i) solistisch versus coöpererend; en (ii) generalistisch versus specialistisch.

\section{BOX 2 INVOEGEN}

De dimensie solistisch versus coöpererend weerspiegelt de mate waarin een bedrijfswetenschapper samen met co-auteurs publiceert. De dimensie generalistisch versus specialistisch geeft aan in hoeverre een auteur zich richt op specifieke tijdschriften. Een viertal voorbeelden kan de typologie verduidelijken: Nooteboom - solistisch generalistisch (I) - schrijft vooral alleen, verspreid over verschillende tijdschriften; Van Raaij - solistisch specialistisch (II) - heeft zijn zes artikelen voornamelijk alleen geschreven, alle in hetzelfde tijdschrift (Journal of Economic Psychology); Koedijk - coöpererend generalistisch (III) - heeft steeds met een co-auteur, in vijf verschillende tijdschriften, gepubliceerd; en Groenewegen - coöpererend specialistisch (IV) - heeft zijn vier artikelen telkens met (een) ander(en) via hetzelfde tijdschrift (Journal of Economic Issues) uitgebracht. Uiteraard zijn ook, in allerlei gradaties, gemengde profielen herkenbaar. Nog vier voorbeelden: toppublicist Boot heeft voornamelijk co-producties afgeleverd (slechts één artikel is alleen geschreven), in vier verschillende tijdschriften (in drie tijdschriften heeft hij twee maal gepubliceerd); veelschrijver Nijman heeft altijd met (een) ander(en) geschreven, vaak in verschillende tijdschriften (zes) maar ook vier keer in de Journal of Econometrics; Hofstede heeft drie keer met en twee keer zonder co-auteur(s) gepubliceerd, waarvan drie maal in hetzelfde tijdschrift (Organization Studies); en Van Witteloostuijn heeft zes artikelen via vijf tijdschriften uitgebracht, drie keer met en drie keer zonder co-auteur.

\subsection{Robuustheid: enkele vingeroefeningen}

Mede in het licht van de classificatie van publicatieprofielen volgen hierna drie alternatieve telexercities. Aan de hand van deze vingeroefeningen kan vervolgens een aantal opmerkingen worden gemaakt. In de eerste plaats is in tabel 15 een alternatieve hitlijst - een top-20 - gereproduceerd met een alternatief wegingalgoritme - een continue weging, met de 'impact scores' als coëfficienten.

\section{TABEL 15 INVOEGEN}

In tabel 16 staat een exercitie waarmee het onderscheid tussen generalisme en specialisme wordt onderbouwd via de vermelding van het aantal verschillende tijdschriften waarin de betrokkene heeft gepubliceerd. Kortheidshalve hebben wij ons overigens beperkt tot de ongewogen top-40 van bedrijfswetenschappers.

\section{TABEL 16 INVOEGEN}

In tabel 17 is een top-20 opgenomen waarin cöoperatie hoger wordt gewaardeerd dan solisme: de 
(neerwaartse) correctie voor co-auteurschappen is geschrapt. Tussen haakjes staat telkens de positie in de bijbehorende 'gecorrigeerde' hitlijst.

\section{TABEL 17 INVOEGEN}

Een vergelijking van de teluitkomsten in de tabellen 15-17 onderling en met de hitlijsten in de tabellen 13-14 geeft aanleiding tot ten minste zeven opmerkingen.

(1) De verandering van discrete naar continue weging leidt tot belangrijke verschuivingen. Binnen de ene subdiscipline circuleren meer tijdschriften en opereren meer wetenschappers dan in de andere, zodat binnen de ene subdiscipline meer artikelen en meer citaten worden 'geproduceerd'. Het 'financiële' duo berichtgeving en financiering beschikt gezamenlijk over 37 specialistische tijdschriften, die in de SSCI onder de noemer 'Business, Finance' worden gerubriceerd, terwijl marketing (12 in de algemene categorie 'Business') en organisatie (23 in de met informatie en besliskunde gedeelde categorie 'Management') zich met minder geclassificeerde tijdschriften tevreden moeten stellen.

(2) Op één 'klapper' kan een publicist jaren teren. De volgende drie voorbeelden zijn illustratief. De stijging van Hofstede en Neuijen in tabel 15 is bij voorbeeld grotendeels respectievelijk volledig te danken aan een gezamenlijk artikel in de Administrative Science Quarterly (met een 'impact score' van 2,191). Zou en Sterken profiteren beide van lange, vaak ook alleen geschreven artikelen [Zou telkens alleen in de Journal of Public Economics en Journal of Comparative Economics (twee artikelen); Sterken tweemaal, waarvan één keer alleen, in Economic Modelling].

(3) Publiceren in 'generieke' tijdschriften - dat wil zeggen: tijdschriften die zich richten op een algemeen publiek van econome(triste)n, sociologen of psychologen - zet veel zoden aan de dijk (zie ook opmerking 6). Met name Boot en Nijman profiteren hiervan. De positie van Boot is bij voorbeeld onaantastbaar omdat hij tweemaal heeft gepubliceerd in het toptijdschrift de American Economic Review (met een 'impact score' van 1,588). Andere voorbeelden zijn Dijkstra, Koedijk en Schotman. Vooral 'financierders' publiceren in niet-specialistische tijdschriften binnen de economische wetenschappen. Dat is geen wonder, omdat in de Angelsaksische academia met name berichtgeving en financiering als een natuurlijk onderdeel van de economische wetenschappen worden beschouwd. In de twintig toptijdschriften in de SSCl-categorie 'Economics' zijn bij voorbeeld drie 'financiële' tijdschriften te vinden. Marketing moet zich alleen zien te redden, terwijl de subdiscipline organisatie enigszins wordt geassocieerd met (toegepaste) psychologie en sociologie.

(4) Een fors aantal bedrijfswetenschappers publiceert regelmatig in dezelfde tijdschriften (zie ook paragraaf 7.8). Hiervan zijn Van Raaij en Groenewegen extreme voorbeelden: hun zes respectievelijk vier artikelen zijn alle verschenen in de Journal of Economic Psychology respectievelijk de Journal of Economic Issues. Ook Nijman is regelmatig in hetzelfde medium terug te vinden - met vier artikelen in de Journal of Econometrics. Hetzelfde geldt voor Hofstede (drie maal in Organization Studies) en Kleijnen (idem in de European Journal of Operations Research).

(5) Gezamenlijk publiceren begint ook in de bedrijfswetenschappen 'usance' te worden. Een groot aantal van de toppublicisten schrijft zelden of nooit alleen. Deze gewoonte lijkt vooral te zijn ingeburgerd binnen de subdiscipline financiering: bij voorbeeld Nijman, Koedijk, Schotman en Wolff hebben louter met co-auteur(s) gepubliceerd. Andere voorbeelden zijn Wedel (marketing) en Boone (organisatie).

(6) De 'impact scores' worden gekenmerkt door structurele divergenties. Opvallend is bij voorbeeld het systematische verschil in de gemiddelde 'impact scores' tussen (sub)disciplines (zie ook opmerking 1). In box 3 staan enkele illustratieve verschillen vermeld op basis van een vergelijking van de SSCI van 1991 en 1993. 
De systematische verschillen tussen economie (de moederdiscipline van berichtgeving en financiering) enerzijds en toegepaste psychologie en sociologie (de thuishaven van menige organisatiewetenschapper) anderzijds zijn opvallend. In het algemeen hebben de 'generieke' tijdschriften hogere 'impact scores' (zie ook opmerking 3).

(7) Vooral subdisciplines zijn gevoelig voor verschuivingen in 'impact scores' van jaar tot jaar (zie box 3). De veranderingen in de 'impact scores' zijn in het algemeen veel groter binnen specialistische subdisciplines dan in de moederdisciplines. Twee sterke stijgers op het niveau van tijdschriften kunnen de gevoeligheid van de subdisciplines illustreren: de Administrative Science Quarterly (binnen 'Management' van positie 3 met 2,191 naar positie 1 met 4,356) en de Review of Financial Studies (in 'Business, Finance' van ongenoteerd naar positie 2 met 2,218). Het gevolg van deze veranderingen is dat auteurs fors op de 'gewogen' ranglijst kunnen stijgen of dalen afhankelijk van het SSCI-jaar. Een vergelijking van twee 'gewogen' hitlijsten - op basis van de SSCI van 1991 en 1993 - maakt dit duidelijk. De samenstellingen van de top, de subtop en het peleton per subdiscipline blijken overigens nauwelijks te wijzigen: een topper blijkt een topper, maar wisselt hooguit stuivertje met een andere topper (bij voorbeeld Boot en Nijman).

De conclusie is duidelijk. Tellen is misschien nog makkelijk, wegen is dat zeker niet - dat blijkt ook hier weer. Misschien dat met de volgende procedure nog de meeste voetangels en klemmen kunnen worden omzeild. Op basis van het gemiddelde van een aantal - bij voorbeeld drie - opeenvolgende 'impact scores' worden per subdiscipline de tijdschriften gerangschikt van hoog naar laag. Vervolgens wordt binnen elke subdiscipline een gelijke driedeling in A-, B- en C-tijdschriften aangebracht, telkens met gelijke gewichten - bij voorbeeld 5, 3 en 1 . Met een gelijke driedeling wordt bedoeld dat binnen elke subdiscipline even veel A- en B-tijdschriften worden onderscheiden (de C-klasse is een restcategorie) bij voorbeeld vijf en tien. Deze procedure heeft drie grote voordelen: (i) de systematische vertekeningen tussen subdisciplines worden geneutraliseerd; (ii) binnen elke subdiscipline worden dezelfde aantallen A- en B-tijdschriften onderscheiden; en (iii) intertemporele verschuivingen worden gedempt.

\subsection{Een vergelijking van methoden}

Alle in de voorgaande tabellen gerapporteerde hitlijsten zijn gebaseerd op dezelfde methodiek: alleen de SSCI-publicaties van een selecte steekproef van publicisten zijn geteld. Daarom worden in tabel 18 , ten slotte, de drie varianten van de top-40 van Van Heerde \& Leeflang (1995) vergeleken met onze 'gewogen' en 'ongewogen' hitlijsten en de Intermediair-lijst van 1991 (51: 25; over de periode 19851989).

\section{TABEL 18 INVOEGEN}

De 1991-editie van de Intermediair-lijst is gekozen om twee redenen. Allereerst was het de laatste top40. Nadien heeft Intermediair nog slechts de top-20 gepubliceerd. Daarnaast was de 1991-editie de laatste Intermediair-hitlijst die was gebaseerd op de uitgebreide selectie van tijdschriften, inclusief plusminus tien vakbladen op het terrein van de berichtgeving/financiering en vier tijdschriften op het gebied van de marketing (zie appendix II). (Organisatie, met uitzondering van het deelgebied industriële economie, is overigens ook op de uitgebreide lijst nauwelijks vertegenwoordigd.)

Uiteraard gaan de vergelijkingen voornamelijk mank. Aan de hand van vier bezwaren kan dat onmiddelijk duidelijk worden gemaakt.

(1) In de eerste plaats overlappen de meetperioden niet of hooguit gedeeltelijk: de lijsten van Van Heerde \& Leeflang (1995) hebben betrekking op de jaren 1986-1992, die van Intermediair (1991) op 1985-1989 en die van ons op 1990-1993. De jonge dertigers van nu - onder meer het 'Limburg- 
se' duo Koedijk en Schotman (en wat te denken van het gouden koppel Boone en Van Witteloostuijn!) - figureren daarom bij voorbeeld niet (of marginaal) in de Intermediair-top-40.

(2) In de tweede plaats is de samenstelling van de steekproeven van publicisten onvergelijkbaar: Van Heerde \& Leeflang (1995) beperken zich tot de tien 'produktiefste' medewerkers per bedrijfswetenschappelijke faculteit of vakgroep, volgens de wetenschappelijke jaarverslagen over de periode 1986-1990, ongeacht het publicatiemedium [nationale en internationale (bijdragen aan) boeken en artikelen]; Intermediair (1991) richt zich op Nederlandse econom(etrist)en, ongeacht werkplek en specialisatie; onze lijsten zijn gebaseerd op een uitgebreide selectie van gepromoveerde bedrijfswetenschappers (zie paragraaf 3). Drie voorbeelden zijn veelzeggend: Nijman (overigens nummer 36 in de Intermediair-top-40 van 1991) en Van Raaij (nummer 27) waren volgens de criteria van Van Heerde \& Leeflang (1995) in 1986-1992 geen bedrijfwetenschappers (maar algemeen econometrist respectievelijk economisch psycholoog), terwijl Boot (niet genoteerd) in deze periode nog hoog en droog in de Verenigde Staten (Northwestern University) verbleef.

(3) In de derde plaats zijn de wegingen verschillend tot stand gekomen: Van Heerde \& Leeflang (1995) maken gebruik van (simulaties met) de resultaten van een vragenlijstonderzoek onder Nederlandse bedrijfswetenschappers (zie verderop) om vervolgens wegingen te koppelen aan de VSNU-indeling in A- tot en met E-publicaties; de Intermediair-top-40 berust op een eigen weging in vier categorieën (wegingen 1 tot en met 4) - van Van Ostende (zie ook verderop); onze wegingen zijn gebaseerd op de 'impact score' van de SSCl en de driedeling van de recente visitatiecommissie psychologie (zie paragraaf 3). Deze wegingverschillen leiden tot merkwaardige - en bijzonder grote - divergenties. Geen enkel bedrijfswetenschappelijk tijdschrift wordt in Intermediair ingedeeld in de hoogste categorie! Bij voorbeeld Management Science heeft weging 2 en 'impact score' 0,921, terwijl de Journal of Econometrics een weging 3 combineert met een 'impact score' van 0,681 .

(4) In de vierde plaats lopen de publicaties waarop de drie tellingen zijn gebaseerd, sterk uiteen: Van Heerde \& Leeflang (1985) nemen alle nationale en internationale (bijdragen aan) boeken en artikelen mee, de Intermediair-tijdschriften (1991) zijn beperkt tot een selectie van 79 internationale economische vakbladen, terwijl onze lijsten zijn samengesteld op basis van de volledige SSCIselectie. In de Intermediair-lijst ontbreken bij voorbeeld vrijwel alle tijdschriften binnen de subdiscipline organisatie, omdat deze veelal een niet-economisch of multidisciplinair karakter hebben. Een sprekend voorbeeld is de Administrative Science Quarterly, dat ondanks een 'impact score' die vergelijkbaar is met Econometrica (in beide gevallen ruim 2), niet in de Intermediair-lijst is opgenomen.

Juist het vierde bezwaar maakt een vergelijking echter interessant. Bij gebrek aan beter zullen we - als een eerste stap - moeten roeien met de riemen die we hebben.

Als ijkpunt voor de vergelijkingen fungeert de 'nationale' lijst van Van Heerde \& Leeflang (1995). Op basis van een vragenlijst terzake onder Nederlandse bedrijfswetenschappers is de weging van de VSNU-categorieën tot stand gekomen, waarbij een onderscheid wordt gemaakt tussen (bijdragen aan) boeken en tijdschriften. Hierbij is wel gecorrigeerd voor co-auteurschappen, conform de Intermediairmethode, maar is het aantal bladzijden niet geteld (alleen het aantal publicaties is geturfd). Het resulterende telalgoritme is

$$
\begin{aligned}
S=W_{t}\left(\alpha_{t A} n t A+\alpha_{t B} n t B+\alpha_{t C} n t C+\alpha_{t D} n t D+\alpha_{t E} n t E\right)+ \\
\quad W_{b}\left(\alpha_{b A} n b A+\alpha_{b B} n b B+\alpha_{b C} n b C+\alpha_{b D} n b D+\alpha_{b E} n b E\right),
\end{aligned}
$$

waarbij $W_{t}$ en $W_{b}$ de gewichten zijn die worden toegekend aan tijdschriftartikelen (t) respectievelijk (bijdragen aan) boeken (b), en $\alpha_{i}$ de weging is van het aantal publicaties ( $n$ ) in VSNU-categorie i. De 'nationale' top-40 (lijst I in tabel 18) is gebaseerd op een respondent die zijn voorkeur uitsprak voor een 
kleine spreiding in de gewichten: $\mathrm{W}_{\mathrm{t}}=0,5 ; \alpha_{\mathrm{tA}}=26 ; \alpha_{\mathrm{tB}}=25 ; \alpha_{\mathrm{tC}}=24 ; \alpha_{\mathrm{tD}}=15 ; \alpha_{\mathrm{tE}}=10 ; \mathrm{W}_{\mathrm{b}}=0,5 ; \alpha_{\mathrm{bA}}=$ 30; $\alpha_{\mathrm{bB}}=28 ; \alpha_{\mathrm{C}}=26 ; \alpha 6=13 ; \mathrm{en}_{\mathrm{b}} \mathrm{Q}=3$. Voor de 'internationale' top-40 (III) zijn de antwoorden genomen van de respondent met een voorkeur voor de grootste spreiding: $W_{t}=0,7 ; \alpha_{A A}=50 ; \alpha_{B}=30$; $\alpha_{t C}=10 ; \alpha_{t D}=6 ; \alpha_{t E}=4 ; W_{b}=0,3 ; \alpha_{b A}=60 ; \alpha_{b B}=30 ; \alpha_{b C}=5 ; \alpha_{b D}=3 ;$ en $\alpha_{b E}=2$. Voor de standaardlijst (II), ten slotte, is uitgegaan van de gemiddelden van de voorkeuren van alle respondenten: $W_{t}=0,55$; $\alpha_{\mathrm{tA}}=35,55 ; \alpha_{\mathrm{tB}}=26,82 ; \alpha_{\mathrm{tC}}=18,55 ; \alpha_{\mathrm{D}}=12,18 ; \alpha_{E}=6,90 ; \mathrm{W}=0,45 ; \alpha_{\mathrm{A}}=34,18 ; \alpha_{B}=26,82 ; \alpha_{C}=$ 19,$36 ; \alpha_{b D}=13,09 ;$ en $\alpha_{b E}=6,55$. De lijsten van Van Heerde \& Leeflang (1995) onderscheiden zich van de andere door het (relatief grote) gewicht dat wordt toegekend aan (i) (bijdragen aan) boeken, (ii) de VSNU-categorieën $C$ tot en met $E$ en (iii) nationale publicaties. Deze observatie is vooral van toepassing op de 'nationale' lijst.

Op basis van een vergelijking van de zes hitlijsten - onder het voorbehoud van de vier bezwaren lijken drie voorzichtige conclusies te kunnen worden getrokken.

(1) Naast de indeling in vier publicatieprofielen in box 2 kan een alternatieve typologie worden gedestilleerd. Een groot aantal bedrijfswetenschappers richt zich op de nationale en/of boeken'markt', terwijl een kleiner aantal vooral publiceert in internationale (SSCI-)tijdschriften. In de 'nationale' top10 van Van Heerde \& Leeflang (1995) zijn bij voorbeeld zeven publicisten te vinden zonder notering in onze hitlijsten: Bemelmans, Heemstra, Dorsman, Bouma, Theeuwes, De Jong en Wortman. Hierbij past overigens de kanttekening dat het denkbaar is dat met name de technisch bedrijfskundigen (onder wie Bemelmans, Heemstra, Theeuwes en Wortmann) in 'Science Index'tijdschriften publiceren. Anderen richten hun vizier voornamelijk op internationale (SSCl-)tijdschriften - bij voorbeeld Hofstede en Wolff. Uiteraard zijn ook hier weer gemengde profielen herkenbaar (vooral Kleijnen, Van Witteloostuijn en Nooteboom).

(2) Het is slechts aan weinig bedrijfswetenschappers voorbehouden het Intermediair-Walhalla te betreden - en dat is na 1991, met de reductie van de tijdschriftenlijst, zelfs vrijwel ondoenlijk. Slechts Nooteboom, Van Witteloostuijn en Wolff staan genoteerd in zowel de 1991-editie van de Intermediair-top-40 als de hitlijsten van Van Heerde \& Leeflang (1995). Op grond van bevindingen bij de samenstelling van de andere hitlijsten lijkt het echter gerechtvaardigd te concluderen dat dit niet wordt veroorzaakt door een geringe, maar veeleer door een andere publicatiedrift van bedrijfswetenschappers: enerzijds door een sterkere oriëntatie op de 'nationale markt' [zie opmerkingen (1) en (3)]; anderzijds door gebruikmaking van niet-Intermediair-tijdschriften (zie appendix II).

(3) Een groot aantal - een forse meerderheid zelfs - bedrijfswetenschappers publiceert helemaal niet in de internationale SSCl-tijdschriften. Slechts 15 van de 40 bedrijfswetenschappers met een notering in de 'nationale' lijst van Van Heerde \& Leeflang (1995) hebben ook een plaats verworven in de rij van 93 bedrijfswetenschappers (van de 315 die in onze tellingen zijn meegenomen) met ten minste één artikel in een $\mathrm{SSCl}$-tijdschrift. Ook hier gelden natuurlijk weer de relativeringen die hiervoor zijn geformuleerd.

\section{EN TOEN?}

De telexercities die hun weg naar de tabellen 1 tot en met 18 hebben weten te vinden, staan ongetwijfeld bol van de fouten. Met verwijzingen naar de zeven standaardfouten (paragraaf 4) moet menig speurder ons echter op onze blunders kunnen wijzen. Misschien dat de analyses in dit memorandum anderen ertoe aanzetten het produktievolume en de produktiviteit van Nederlandse bedrijfswetenschappen en -schappers op alternatieve manieren in kaart te brengen. Een mooi voorbeeld van een alternatieve methode is Zivney \& Bertin (1992), die over een 25-jarige periode (1963-1987) de publicatieloopbaan van Amerikaanse 'financierders' hebben getraceerd. Een bevinding is bij voorbeeld dat 388 van de 938 gepromoveerden (41\%) vijf jaar na de promotie ten minste één artikel heeft gepubliceerd in één van de negentien vooraanstaande 'financiële' vakbladen. Is in vergelijking met deze produktie in het 
bedrijfswetenschappelijke Mekka de Nederlandse conduitestaat goed of slecht? Een ander braakliggend onderzoekterrein betreft het waarom van verschillen in produktiviteit binnen de Nederlandse bedrijfswetenschappen (voor een voorbeeld van dergelijk onderzoek zie Long, McGinnes \& Allison, 1993). Waarom is bij voorbeeld de Maastrichtse faculteit in 1990-1993 een hofleverancier van produktieve bedrijfswetenschappers geweest, en de VU absoluut niet? Of op het niveau van de individuele publicist: is een vertrek naar het bedrijfswetenschappelijke Walhalla - de Verenigde Staten - bevordelijk voor de individuele produktiviteit (Van Dalen, 1995)?

De oproep aan het einde van paragraaf 4 spreekt voor zichzelf. Slechts op basis van herhaalde metingen, waarbij ook de robuustheid van de gehanteerde methode wordt belicht, is het mogelijk gefundeerde uitspraken te doen die minder tijdgebonden zijn. Binnen berichtgeving is bij voorbeeld de ster van Maijoor (RL) inmiddels (in 1994-1995) aan het firmament verschenen, terwijl hetzelfde geldt voor Barkeman (KUB) binnen organisatie. Vervolgmetigen zullen deze dynamiek bloot kunnen leggen. De slotvraag is natuurlijk: wat hebben we hier nou allemaal aan? Het antwoord is uiteraard een kort maar krachtig NIETS. Wij troosten ons echter met de gedachte dat dit memorandum waarschijnlijk een veel grotere oplage zal mogen beleven dan menige poëziebundel - zij het, helaas, dat met aan zekerheid grenzende waarschijnlijkheid de weg naar een SSCI-tijdschrift is geblokkeerd vanwege de nationale oriëntatie van dit geschrift. 


\section{REFERENTIES}

Dalen, H.P. van

1995

Frey, B.S. \&

R. Eichenberger

1993

Gans, J.S. \& G.B. Shepherd 1994

Heerde, H. van \& P.S.H.

Leeflang

1995

Klamer, A. \& D. Collander 1990

Laband, D.N. \& M.J. Piette 1994

Long, J.S., R. McGinnes

\& P.D. Allison

1993

Witteloostuijn, A. van

1995

Zivney, T.L. \& W.J. Bertin 1992
'Measuring giants and dwarfs: assessing the quality of economic researchers', Research Memorandum TI-30, Amsterdam/Rotterdam: Tinbergen Institute.

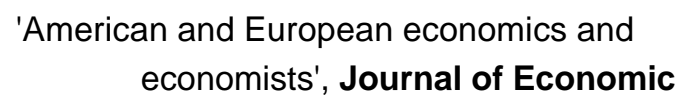

'How are the mighty fallen: rejected classic articles by leading economists', Journal of Economic Perspectives, $8,165-179$

'De top-40 van bedrijfseconomen en bedrijfskundigen (1986-1992)', Onderzoekmemorandum, Groningen: Faculteit der Economische Wetenschappen.

The making of an economist, Boulder: Westview Press.

'The relative impacts of economics journals: 1970-1990', Journal of Economic Literature, 32, 640-666.

'Rank advancement in academic careers: sex differences and the effects of productivity', American Sociological Review, 58, 703-722.

'Een verkenning van het Nederlandse onderzoek in de bedrijfswetenschappen', Maandblad voor accountancy en bedrijfseconomie, 69 , in druk.

'Publish or perish: what the competition is really doing', Journal of Finance, 47, 295-329. 


\section{APPENDIXI. WETENSCHAPPERS}

In het navolgende worden alle bedrijfswetenschappers waarvan de publicaties in het tijdvak 1990-1993 via de SSCI zijn getraceerd, in alfabetische volgorde gerangschikt. Afgezien van de opmerkingen in de hoofdtekst, zijn nog drie kanttekeningen op hun plaats:

(1) Het was niet altijd eenvoudig een bedrijfswetenschapper uniek te classificeren als contribuant aan een specifieke deeldiscipline. Deze moeilijkheid deed zich - weer - vooral voor binnen het vakgebied organisatie. Vooral op het raakvlak informatie/logistiek is het moeilijk arbitraire beslissingen volledig uit te sluiten. Het is daarom denkbaar dat een aantal van onze taxaties voor discussie vatbaar is.

(2) Hopelijk is het aantal spelfouten gering. Vooral in de sfeer van voorletters en tussenvoegsels (van, de, van der, etc.) kunnen fouten zijn geslopen. Daarnaast kan de (inconsistente) Vlaamse omgang met tussenvoegsels verwarrend zijn (bij voorbeeld: DeBondt, de Bondt of De Bondt).

(3) Bedrijfswetenschappers met dubbelaanstellingen zijn toegewezen aan de getaxeerde 'hoofdinstelling'. Ook hierover kunnen de meningen verschillen. 


\section{APPENDIX II. TIJDSCHRIFTEN}

In het navolgende staat alle SSCl-tijdschriften vermeld waarin ten minste éénmaal is gepubliceerd door een Nederlandse wetenschapper (appendix I) gedurende het tijdvak 1990-1993. Het aantal artikelen per tijdschrift is veelal een overschatting, omdat niet is gecorrigeerd voor dubbeltellingen.

Academy of Management Journal

Administrative Science Quarterly

Advances in Consumer Research

American Behavioral Scientist

American Economic Review

Annals of Tourism Research

Applied Economics

Applied Psychological Measurement

British Journal of General Practice

British Journal of Mathematical \& Statistical Psychology

Canadian Public Administration

Curriculum Inquiry

De Economist

Econometrica

Economica

Economic Journal

Economics Letters

Economic Modelling

Economicko Mathematicky Obzor

Educational Gerontology

Environment \& Planning C - Government \& Policy

Ergonomics

European Economic Review

European Journal of Psychiatry

European Journal of Operations Research

Financial Management

Futures

Gedrag en Gezondheid

Health Policy

History of Political Economy

IFIP Transactions A - Computer Science \& Technology

Information \& Management

Insurance, Mathemathics \& Economics

International Economic Review

International Journal of Industrial Organization

International Journal of Public Administration

International Sociology

Irish Journal of Psychology

Journal of Accounting and Business Studies

Journal of Applied Econometrics

Journal of Applied Economics

Journal of Banking \& Finance

Journal of Business Economics

Journal of Business Research

Journal of Business Venturing

Journal of Classification

Journal of Common Market Studies

Journal of Comparative Economics

Journal of Consumer Policy

Journal of Consumer Research

Journal of Econometrics

Journal of Economics

Journal of Economic Behavior \& Organization

Journal of Economic Issues

Journal of Economic Psychology 
Journal of Finance

Journal of Forecasting

Journal of Futures Markets

Journal of Information Science

Journal of International Business Studies

Journal of International Economics

Journal of International Money \& Finance

Journal of the Japanese and International Economies

Journal of Management Studies

Journal of Marketing Research

Journal of Portfolio Management

Journal of Product Innovation Management

Journal of Public Economics

Journal of Retailing

Journal of Scientific \& Industrial Research

Journal of Social Behavior \& Personality

Journal of Social Psychology

Journal of World Trade

Lecture Notes in Economics \& Mathematical Systems

Library Journal

Long Range Planning

Management Science

Management International Review

Mathematical Social Sciences

Medical Decision Making

Minerva

Netherlands Journal of Social Sciences

Operations Research

Organization Studies

Perceptual and Motor Skills

Psychological Reports

Psychometrika

Public Relations Review

$R$ \& D Management

Research Policy

Review of Financial Studies

Review of Income and Wealth

Scientometrics

Small Business Economics

Social Science \& Medicine

Strategic Management Journal

Technological Forecasting and Social Change 


\section{APPENDIX III. VAKGROEPEN}

Binnen instellingen zijn de medewerkers van de vakgroepen (of secties) meegenomen (ten behove van de samenstelling van lijst $A$; zie appendix I) die zich (lijken te) bewegen op het terrein van één van de vier bedrijfswetenschappelijke subdisciplines. Hierbij is overigens niet a priori elke medewerker in lijst $A$ opgenomen (zie de hoofdtekst en appendix I). Hiervoor is ook additionele informatie gebruikt (uit bij voorbeeld studiegidsen en wetenschappelijke jaarverslagen). In het navolgende worden deze vakgroepen/secties vermeld per instelling (in alfabetische volgorde). Indien mogelijk, wordt (worden) tussen haakjes de relevante subdiscipline(s) vermeld.

\section{FdB/EUR}

Financieel management

Management van technologie en innovatie

(Berichtgeving en financiering)

Marketing management

Organisatie- en personeelswetenschappen

(Organisatie)

(Marketing)

Strategie en omgeving

(Organisatie)

(Organisatie)

\section{$\underline{F d B / R U G}$}

Informatie en organisatie

(Organisatie)

Markt en onderneming

Organisatie, technologie en innovatie

(Organisatie)

\section{FdEWB/RL}

Berichtgeving, administratieve organisatie en accountancy

(Berichtgeving)

Financiering

(Financiering)

Internationale bedrijfskunde

(Organisatie)

Marketing en marktonderzoek

(Marketing)

Organisatie

(Organisatie)

\section{FdEW/EUR}

Accountancy, administratieve organisatie en bestuurlijke informatiekunde Boekhouden en financiële rekenkunde

Commerciële beleidsvorming en commerciële economie

Econommische organisatievormen

Economische sociologie en psychologie

Financiering en belegging

Interne organisatie

Kosten- en winstbepalingsvraagstukken

(Berichtgeving)

(Berichtgeving)

(Marketing)

(Organisatie)

(Organisatie)

(Financiering)

(Organisatie)

(Berichtgeving)

\section{FdEW/KUB}

Accountancy

Boekhouden

Kosten-waarde-winst

Marketing en marktonderzoek

Ondernemingsfinanciering

Organisatie

(Berichtgeving)

(Berichtgeving)

(Berichtgeving)

(Marketing)

(Financiering)

(Organisatie)

\section{FdEW/RUG}

Financieel management

(Berichtgeving en financiering)

Marketing en marktonderzoek

(Marketing)

Organisatie en leiding

\section{FdEW/UvA}

Accountancy

(Berichtgeving)

Bedrijfsorganisatie en arbeidsverhoudingen

(Organisatie)

Externe organisatie

(Organisatie)

Financieel management

(Financiering)

Marktbeleid en marktonderzoek

(Marketing)

\section{$\underline{F d E W / V U}$}


(Marketing en organisatie)

\section{Financiering}

(Financiering)

Kosten- en winstvraagstukken

(Berichtgeving)

Postdoctorale opleidingen

(Berichtgeving) 


\section{BOX 1. De eerste brief}

51111111111111111111111111111111111110

Aan: A. van Witteloostuijn

C. Boone

MANOR

Faculteit der Economische Wetenschappen en Bedrijfskunde

Rijksuniversiteit Limburg

Postbus 616

6200 MD Maastricht

Geachte heren,

Met grote belangstelling heb ik kennis genomen van uw pogingen de produktiviteit van Nederlandse bedrijfswetenschappers te meten. Na herhaalde lezing kan ik het echter niet nalaten u opmerkzaam te maken, zonder overigens uitputtend te kunnen en willen zijn, op een groot aantal fouten.

(1) Dat optellen niet voor iedereen even gemakkelijk is, merk ik aan mijn eigen kinderen. Mijn ongewogen puntentotaal is 128, en geen 124 (het gewogen puntentotaal heb ik niet gecontroleerd).

(2) Een aantal talentrijke en produktieve medewerkers is weggelaten louter en alleen vanwege hun drs-titel. Een duidelijk voorbeeld daarvan is René Olie, universitair docent alhier. Daarnaast zijn belangrijke deeltijdhoogleraren niet opgenomen (bij voorbeeld Arndt Sorge, die als deeltijdhoogleraar HRM een onmisbare rol alhier vervult).

(3) De SSCl-lijst van tijdschriften is evident incompleet. Een belangrijk internationaal tijdschrift als de European Journal of Political Economy ontbreekt, terwijl een obscuur blad als de Journal of Evolutionary Theory prominent figureert; het ene nationale periodiek is opgenomen (bij voorbeeld het Nederlandse De Economist), terwijl het andere door afwezigheid schittert (onder meer het Franse Economie appliquée en het Italiaanse Metroeconomica). Ook binnen subdisciplines is sprake van inconsistenties: waarom de Journal of Industrial Economics en International Journal of Industrial Organization wel, maar de Review of Industrial Organization en Small Business Economics niet? Veel erger is dat cruciale publicaties niet worden meegeteld omdat zij toevallig niet in een internationaal tijdschrift zijn terecht gekomen. Vooral (bijdragen aan) boeken, recensies en nationale publicaties zijn onmisbaar in het (inter)nationale wetenschappelijke debat. Mijn Collega

5111111111111111111111111111111111110 
Vervolg box 1

5)111111111111111111111111111111111110

Ad van Iterson publiceert bij voorbeeld veel (in) boeken. We weten allemaal dat de strijd om toegang tot de internationale tijdschriftenmarkt een merkwaardige loterij is, waarin toeval in plaats van kwaliteit veelal de doorslag geeft (Gans \& Shepherd, JEP, 1994, 8: 165-179).

(4) De weging van de drie categorieën tijdschriften is volstrekt arbitrair: waarom drie?; en waarom met wegingen 1, 2 en 3 ? Het is opvallend dat de uitvinders van deze methode, de visitatiecommissie psychologie, hierover niets te zeggen hebben. Overigens versterkt deze methodiek de ongelijkheid der subdisciplines (zie verderop).

(5) De ontwikkelingen gaan snel. Met de doorbraak van Christophe Boone en de komst van Gerard Pfann, bij voorbeeld, is het beeld van de organisatiegroep alhier al weer fors veranderd. Ook ikzelf heb inmiddels gepubliceerd - of sta op het punt om dat te doen - in onder meer Management Science, Organization Studies en Strategic Management Journal.

(6) De ene subdiscipline is de andere niet. Het geeft geen pas de produktiviteit van berichtgeving te vergelijken met die van financiering, gezien de evidente - en terechte! - nationale oriëntatie van de eerste.

(7) Het nut van al dat telwerk ontgaat mij. Het Amerikaniseren van het Nederlandse (en Europese) wetenschappelijke bedrijf zet onstuitbaar door. Dat betekent de introductie van een onaangename en inproduktieve concurrentieslag ('publish or perish') en een voortzettende mathematisering en 'irrelevantisering' van het vak (Klamer \& Colander, 1990; en Gans \& Shepherd, 1995). Het lijkt erop dat de bedrijfseconomie de algemene econom(etr)ie hierin slaafs volgt.

Helaas heeft lezing van uw proeve mij gesterkt in mijn (voor)oordeel dat het niet goed gaat met ons vak: 'We are thus inclined to conclude on a rather pessimistic note: the future of economics as a relevant social science seems rather gloomy' (Frey \& Eichenberger, JEP, 1993, 7: 192).

Met vriendelijke groet,

hoogachtend,

Prof. dr A. van Witteloostuijn

S11111111111111111111111111111111110 
TABEL 1. Produktie en produktiviteit per faculteit

\begin{tabular}{||lr|r|r|r|r|r||}
\hline \hline INSTELLING & $\mathbf{( A )}$ & P & \multicolumn{1}{c|}{ B } & G & \multicolumn{1}{c|}{ P/G } & \multicolumn{1}{c|}{ B/G } \\
\hline \hline EUR & $\mathbf{( 1 7 )}$ & 379,8 & 218,8 & 39 & 9,7 & 5,6 \\
EUR/FB & $\mathbf{( 1 6 )}$ & 451,0 & 263,0 & 35 & 12,9 & 7,5 \\
KUB & $\mathbf{( 2 0 )}$ & 452,4 & 263,1 & 27 & 16,8 & 9,7 \\
RUG & $\mathbf{( 1 9 )}$ & 402,3 & 275,4 & 22 & 18,3 & 12,5 \\
RUG/FB & $\mathbf{( 5 )}$ & 87,0 & 73,0 & 27 & 3,2 & 2,7 \\
RL & $\mathbf{( 4 0 )}$ & 998,1 & 555,1 & 30 & 33,3 & 18,5 \\
UvA & $\mathbf{( 1 5 )}$ & 559,2 & 317,8 & 20 & 27,9 & 15,9 \\
VU & $\mathbf{( 3 )}$ & 85,2 & 38,4 & 25 & 3,4 & 1,5 \\
\hline \hline Totaal & $\mathbf{( 1 3 5 )}$ & 3415,0 & 2004,6 & 225 & 15,2 & 8,9 \\
\hline \hline
\end{tabular}

$\mathrm{A} \quad=\quad$ totale aantal gepubliceerde artikelen

$\mathrm{P} \quad$ = $\quad$ voor co-auteurschappen gecorrigeerde aantal punten via publicaties in internationale tijdschriften (S bij $\mathrm{W}$ is 1,2 B of 3 : zie paragraaf 3 )

$\mathrm{B} \quad=\quad$ voor co-auteurschappen gecorrigeerde aantal punten via publicaties in internationale tijdschriften (S bij $\mathrm{W}$ is 1 : zie G = $\quad \begin{array}{ll}\text { paragraaf 3) } & \text { aantal gepromoveerde stafmedewerkers }\end{array}$

EUR $=$ Econom(etr)ie Erasmus Universiteit Rotterdam

$\mathrm{EUR} / \mathrm{FB}=\quad$ Bedrijfskunde Erasmus Universiteit Rotterdam

$\mathrm{KUB}=$ Econom(etr)ie Katholieke Universiteit Brabant

RUG $\quad$ Econom(etr)ie Rijksuniversiteit Groningen

$\mathrm{RUG} / \mathrm{FB}=\quad$ Bedrijfskunde Rijksuniversiteit Groningen

$\mathrm{RL} \quad=\quad$ Bedrijfskunde/Econom(etr)ie Rijksuniversiteit Limburg

UvA $=\quad$ Econom(etr)ie Universiteit van Amsterdam

$\mathrm{VU} \quad=\quad$ Econom(etr)ie Vrije Universiteit 
TABEL 2. Produktie en produktiviteit per subdiscipline

\begin{tabular}{|c|c|c|c|c|c|c|c|}
\hline SUBDISCIPLINE & INSTELLING & (A) & $\mathbf{P}$ & $\mathrm{B}$ & $\mathbf{G}$ & $\mathbf{P} / \mathbf{G}$ & $\mathbf{B} / \mathbf{G}$ \\
\hline Berichtgeving & $\begin{array}{l}\text { EUR } \\
\text { EUR/FB } \\
\text { KUB } \\
\text { RUG } \\
\text { RUG/FB } \\
\text { RL } \\
\text { UvA } \\
\text { VU } \\
\end{array}$ & $\begin{array}{l}(0) \\
(1) \\
(0) \\
(0) \\
(0) \\
(1) \\
(0) \\
(0)\end{array}$ & $\begin{array}{r}0,0 \\
10,0 \\
0,0 \\
0,0 \\
0,0 \\
33,0 \\
0,0 \\
0,0 \\
\end{array}$ & $\begin{array}{r}0,0 \\
10,0 \\
0,0 \\
0,0 \\
0,0 \\
16,5 \\
0,0 \\
0,0 \\
\end{array}$ & $\begin{array}{l}5 \\
3 \\
5 \\
2 \\
1 \\
6 \\
5 \\
7\end{array}$ & $\begin{array}{l}0,0 \\
3,3 \\
0,0 \\
0,0 \\
0,0 \\
5,5 \\
0,0 \\
0,0 \\
\end{array}$ & $\begin{array}{l}0,0 \\
3,3 \\
0,0 \\
0,0 \\
0,0 \\
2,8 \\
0,0 \\
0,0 \\
\end{array}$ \\
\hline Financiering & $\begin{array}{l}\text { EUR } \\
\text { EUR/FB } \\
\text { KUB } \\
\text { RUG } \\
\text { RUG/FB } \\
\text { RL } \\
\text { UvA } \\
\text { VU } \\
\end{array}$ & $\begin{array}{r}(9) \\
(0) \\
(12) \\
(7) \\
(0) \\
(13) \\
(13) \\
(0) \\
\end{array}$ & $\begin{array}{r}166,8 \\
0,0 \\
286,0 \\
225,9 \\
0,0 \\
352,8 \\
513,2 \\
0,0 \\
\end{array}$ & $\begin{array}{r}101,8 \\
0,0 \\
150,3 \\
145,9 \\
0,0 \\
174,7 \\
271,8 \\
0,0 \\
\end{array}$ & $\begin{array}{r}10 \\
2 \\
6 \\
7 \\
2 \\
8 \\
7 \\
5 \\
\end{array}$ & $\begin{array}{r}16,7 \\
0,0 \\
47,7 \\
32,3 \\
0,0 \\
44,1 \\
73,3 \\
0,0 \\
\end{array}$ & $\begin{array}{r}10,2 \\
0,0 \\
25,1 \\
20,8 \\
0,0 \\
21,8 \\
38,8 \\
0,0 \\
\end{array}$ \\
\hline Marketing & $\begin{array}{l}\text { EUR } \\
\text { EUR/FB } \\
\text { KUB } \\
\text { RUG } \\
\text { RUG/FB } \\
\text { RL } \\
\text { UvA } \\
\text { VU } \\
\end{array}$ & $\begin{array}{l}(1) \\
(9) \\
(0) \\
(9) \\
(0) \\
(2) \\
(0) \\
(2)\end{array}$ & $\begin{array}{r}21,0 \\
313,5 \\
0,0 \\
131,7 \\
0,0 \\
22,0 \\
0,0 \\
42,0 \\
\end{array}$ & $\begin{array}{r}21,0 \\
153,5 \\
0,0 \\
84,8 \\
0,0 \\
22,0 \\
0,0 \\
24,0 \\
\end{array}$ & $\begin{array}{l}8 \\
8 \\
5 \\
8 \\
3 \\
5 \\
2 \\
2 \\
\end{array}$ & $\begin{array}{r}2,6 \\
39,2 \\
0,0 \\
16,5 \\
0,0 \\
4,4 \\
0,0 \\
21,0 \\
\end{array}$ & $\begin{array}{r}2,6 \\
19,2 \\
0,0 \\
10,6 \\
0,0 \\
4,4 \\
0,0 \\
12,0 \\
\end{array}$ \\
\hline Organisatie & $\begin{array}{l}\text { EUR } \\
\text { EUR/FB } \\
\text { KUB } \\
\text { RUG } \\
\text { RUG/FB } \\
\text { RL } \\
\text { UvA } \\
\text { VU } \\
\end{array}$ & $\begin{array}{r}(7) \\
(6) \\
(8) \\
(3) \\
(5) \\
(24) \\
(2) \\
(1) \\
\end{array}$ & $\begin{array}{r}192,0 \\
127,5 \\
166,4 \\
44,7 \\
87,0 \\
590,2 \\
46,0 \\
43,2 \\
\end{array}$ & $\begin{array}{r}96,0 \\
99,5 \\
112,8 \\
44,7 \\
73,0 \\
342,0 \\
46,0 \\
14,4 \\
\end{array}$ & $\begin{array}{r}16 \\
22 \\
11 \\
5 \\
21 \\
11 \\
6 \\
11\end{array}$ & $\begin{array}{r}12,0 \\
5,6 \\
15,1 \\
8,9 \\
4,1 \\
53,7 \\
7,7 \\
3,9 \\
\end{array}$ & $\begin{array}{r}6,0 \\
4,5 \\
10,3 \\
8,9 \\
3,5 \\
31,1 \\
7,7 \\
1,3 \\
\end{array}$ \\
\hline $\begin{array}{l}\text { Totaal } \\
\text { subdisciplines }\end{array}$ & $\begin{array}{l}\text { Berichtgeving } \\
\text { Financiering } \\
\text { Marketing } \\
\text { Organisatie }\end{array}$ & $\begin{array}{r}(2) \\
(54) \\
(23) \\
(56) \\
\end{array}$ & $\begin{array}{r}43,0 \\
1544,8 \\
530,2 \\
1297,0 \\
\end{array}$ & $\begin{array}{r}26,5 \\
844,6 \\
305,3 \\
828,3 \\
\end{array}$ & $\begin{array}{r}34 \\
47 \\
41 \\
103 \\
\end{array}$ & $\begin{array}{r}1,3 \\
33,8 \\
12,9 \\
12,5 \\
\end{array}$ & $\begin{array}{r}0,8 \\
17,9 \\
7,4 \\
8,0 \\
\end{array}$ \\
\hline
\end{tabular}


TABEL $3 . \quad$ '(On)gewogen' top-2 berichtgeving

51111111111111111111111111111111111110

POSITIE NAAM (aantal artikelen)

PUNTEN

INSTELLING

S111111111111111111111111111111110

$1 \quad$ Buijink (1)

$2 \quad$ Van der Tas (1)

5111111111111111111111111111111111110

$10(10)^{33(16,5) \quad \text { EUR/FB }}{ }^{R}$




\section{TABEL $4 . \quad$ 'Ongewogen' top-15 financiering}

51111111111111111111111111111111111110 POSITIE NAAM (aantal artikelen)

\begin{tabular}{|c|c|}
\hline \multicolumn{2}{|c|}{511111111111111111111111111111111110} \\
\hline 1 & Nijman (10) \\
\hline 2 & Boot (7) \\
\hline 3 & Zou (3) \\
\hline 4 & Koedijk (6) \\
\hline 5 & Sterken (2) \\
\hline 6 & Schotman (4) \\
\hline 7 & Dijkstra (3) \\
\hline 8 & Perotti (3) \\
\hline 9 & Van de Sar (2) \\
\hline 10 & Wolff (3) \\
\hline 11 & Spronk (2) \\
\hline 12 & Bossaerts (1) \\
\hline 13 & Kofman (2) \\
\hline $14-15$ & Vorst (2) \\
\hline $14-15$ & Van Loon (1) \\
\hline
\end{tabular}

\section{PUNTEN INSTELLING}

$\begin{array}{cccl} & 120 & & \text { KUB } \\ & 116 & & \text { UvA } \\ 115 & & \text { UvA } & \\ & 74 & & \text { RL } \\ & 72 & & \text { RUG } \\ 69 & & \text { RL } & \\ & 50 & & \text { RUG } \\ & 41 & & \text { UvA } \\ 32 & & \text { EUR } & \\ & 31 & & \text { RL } \\ & 25 & & \text { EUR } \\ 23 & & \text { KUB } & \\ & 19 & & \text { EUR }\end{array}$

18

18 EUR 


\section{TABEL 5. ' 'Gewogen' top-15 financiering}

51111111111111111111111111111111111110 POSITIE NAAM (aantal artikelen)

$\begin{array}{lc}511111111111111111111111111111111111110 \\ 1 & \text { Boot (7) } \\ 2 & \text { Nijman (10) } \\ 3 & \text { Zou (3) } \\ 4 & \text { Koedijk (6) } \\ 5 & \text { Schotman (4) } \\ 6 & \text { Dijkstra (3) } \\ 7 & \text { Perotti (3) } \\ 8 & \text { Sterken (2) } \\ 9 & \text { Van de Sar (2) } \\ 10-11 & \text { Wolff (3) } \\ 10-11 & \text { Kofman (2) } \\ 12 & \text { Spronk (2) } \\ 13 & \text { Bossaerts (1) } \\ 14-15 & \text { Vorst (2) } \\ 14-15 & \text { Van Loon (1) } \\ 51111111111111111111111111111111111110\end{array}$

\section{PUNTEN INSTELLING}

159

151

255

KUB

UvA RL

$153 \mathrm{RL} R$

$123 \quad$ RUG

76 UvA

$72 \quad$ RUG

$64 \quad$ EUR

$49 \quad \mathrm{RL}$

$49 \quad$ EUR

$23 \quad 25 \quad$ KUB

$21 \quad$ EUR

RUG 
TABEL 6. ' 'Ongewogen' top-12 marketing

51111111111111111111111111111111111110 POSITIE NAAM (aantal artikelen) 5)1111111111111111111111111111111110 $1 \quad$ Van Raaij (6)

2 Wedel (4)

$3 \quad$ Krijnen (3)

$4 \quad$ Bamossy (2)

$5 \quad$ Verbeke (1)

$6 \quad$ Van Riel (1)

7 Kasper (1)

8 De Ruyter (1)

9-10 Leeflang (1)

9-10 Zwart (1)

11-12 Jansen-Verbeke (1)

11-12 Wieringa (1)

511111111111111111111111111111111110

\section{PUNTEN INSTELLING}

120

EUR/FB

$43 \quad$ RUG

24

26

VU

RUG

$21 \quad$ EUR

20

EUR/FB

9

$\mathrm{RL}$

$\mathrm{RL}$

RUG

RUG 


\section{TABEL 7. 'Gewogen' top-12 marketing}

51111111111111111111111111111111111110 POSITIE NAAM (aantal artikelen) 5)1111111111111111111111111111111110 $1 \quad$ Van Raaij (6)

$2 \quad$ Krijnen (3)

3 Wedel (4)

$4 \quad$ Bamossy (2)

$5 \quad$ Van Riel (1)

$6 \quad$ Verbeke (1)

7 Wierenga (1)

8-9 Jansen-Verbeke (1)

8-9 Kasper (1)

10 De Ruyter (1)

11-12 Leeflang (1)

11-12 Zwart (1)

511111111111111111111111111111111110

\section{PUNTEN INSTELLING}

241

EUR/FB

42

RUG

57 RUG

13

20

$40 \quad$ EUR/FB

21 EUR

EUR/FB

EUR/FB

$R L$

$\mathrm{RL}$

RUG

RUG 


\section{TABEL 8. 'Ongewogen' top-20 organisatie}

51111111111111111111111111111111111110 POSITIE NAAM (aantal artikelen) 5111111111111111111111111111111111110 $1 \quad$ Van Witteloostuijn (6) 2-3 Hofstede (5)

2-3 Hagedoorn (3)

$4 \quad$ Noorderhaven (2)

$5 \quad$ Groenewegen (4)

$6 \quad$ Nooteboom (3)

7 Boone (8)

8 Huygen (2)

$9 \quad$ Maas (3)

$10 \quad$ Elfring (1)

11-12 Deneffe (2)

11-12 Beije (2)

13-14 Lammers (1)

13-14 Thio (1)

15 Koopman (1)

$16 \quad$ Schreuder (2)

17-18 Thierry (2)

17-18 Romme (1)

19 Van Wegberg (2)

$20 \quad$ Mijs (1)

5111111111111111111111111111111111110

$\mathrm{KUN}=$ Katholieke Universiteit Nijmegen

RUL $\quad$ Rijksuniversiteit Leiden

FdSW $=$ Faculteit der Sociale Wetenschappen

\section{PUNTEN INSTELLING}

$124 \quad \mathrm{RL}$

57 RL-emeritus

$57 \quad \mathrm{RL}$

$48 \quad$ EUR

47

$45 \quad \mathrm{RL}$

$40 \quad$ KUN

$38 \quad \mathrm{EUR} / \mathrm{FB}$

$37 \quad$ EUR/FB

$36 \quad \mathrm{RL}$

$36 \quad$ EUR

RUL-emeritus

32 UvA

$30 \quad$ RUL

$28 \quad \mathrm{RL}$

$27 \quad \mathrm{KUB} / \mathrm{FdSW}$

$27 \quad \mathrm{RL}$

20

$24 \quad \mathrm{RL}$

RUL 


\section{TABEL 9. 'Gewogen' top-20 organisatie}

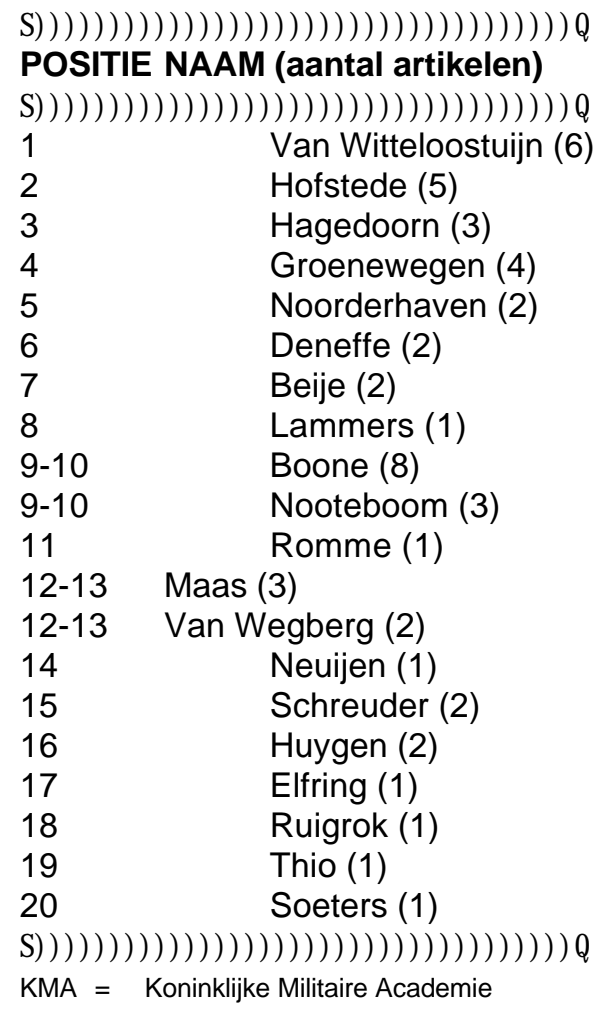

\section{PUNTEN INSTELLING}

178

142

135

$\mathrm{RL}$

$R L$-emeritus

$R L$ 95

72

64

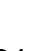

61

61

48

48

41

$54 \quad \mathrm{RUG} / \mathrm{FB}$

RUL-emeritus

4

$\begin{array}{ll}\mathrm{RL} & \\ \mathrm{RL} & \mathrm{VU} \\ & \text { KUN } \\ & \text { EUR/FB } \\ & \text { EUR/FB } \\ & \text { UVA } \\ & \text { KMA }\end{array}$




\section{TABEL 10. '(On)gewogen' top-3 overig}

51111111111111111111111111111111111100 POSITIE NAAM (aantal artikelen)

511111111111111111111111111111111110

$1 \quad$ Kleijnen (6)

2 In 't Veld (1)

$2 \quad$ Algera (1)

5111111111111111111111111111111111110

TUD = Technische Universiteit Delft

TUE = Technische Universiteit Eindhoven

\section{PUNTEN INSTELLING}

33 (17) 136 (82) TUD

9 (9) TUE 
TABEL 11. 'Ongewogen' top-10 Vlaanderen

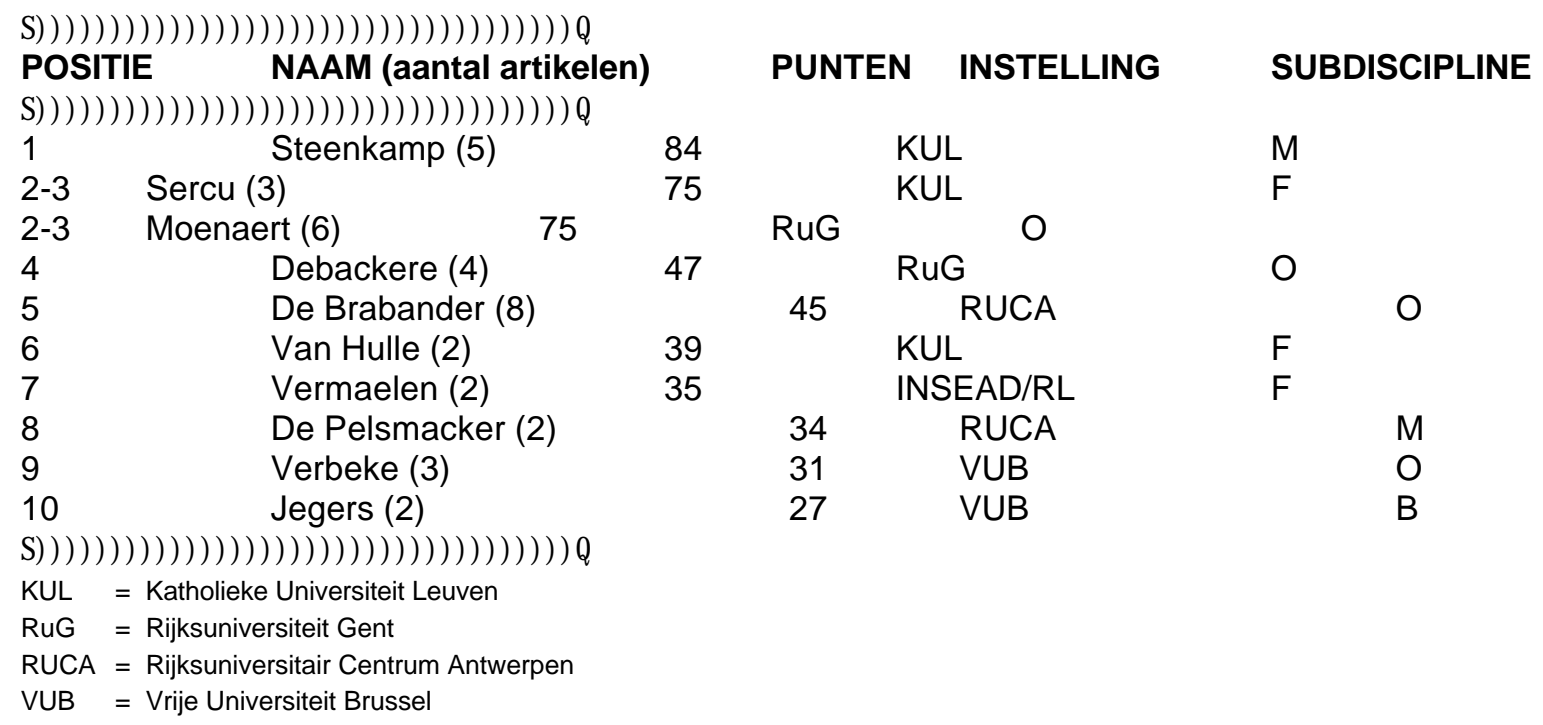




\section{TABEL 12. 'Gewogen top-10 Vlaanderen}

51111111111111111111111111111111111110 POSITIE NAAM (aantal artikelen) 511111111111111111111111111111111110

1

2

3

4

5

6

7

8

9

10

5111111111111111111111111111111111110

Sercu (3)

Moenaert (6)

Vermaelen (2)

De Brabander (8)

Jegers (2)

Verbeke (3)

Debackere (4)

Van Hulle (2)

De Pelsmacker (2)
Steenkamp (5) 133

75

73

73

95

6

61
59

59
50

47

39

34

PUNTEN INSTELLING

SUBDISCIPLINE

$95 \mathrm{KUL}$ KUL

RuG

INSEAD/RL

RUCA

VUB

VUB

M

$\mathrm{F}$

RuG

KUL

RUCA
$F$

O

O

B

O

$\mathrm{F}$

M 
TABEL 13. 'Ongewogen' top-40 bedrijfswetenschappen

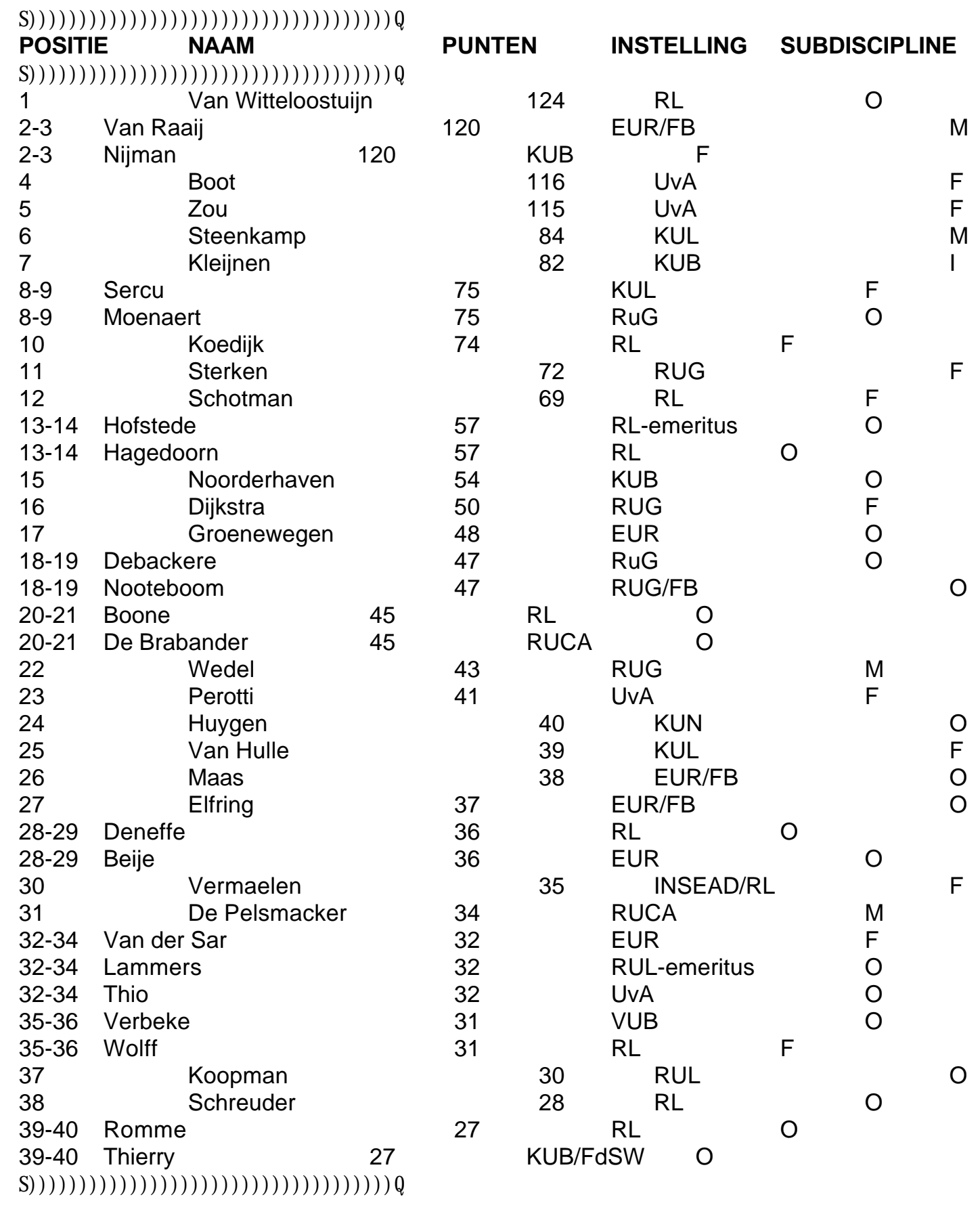


TABEL 14. 'Gewogen' top-40 bedrijfswetenschappen

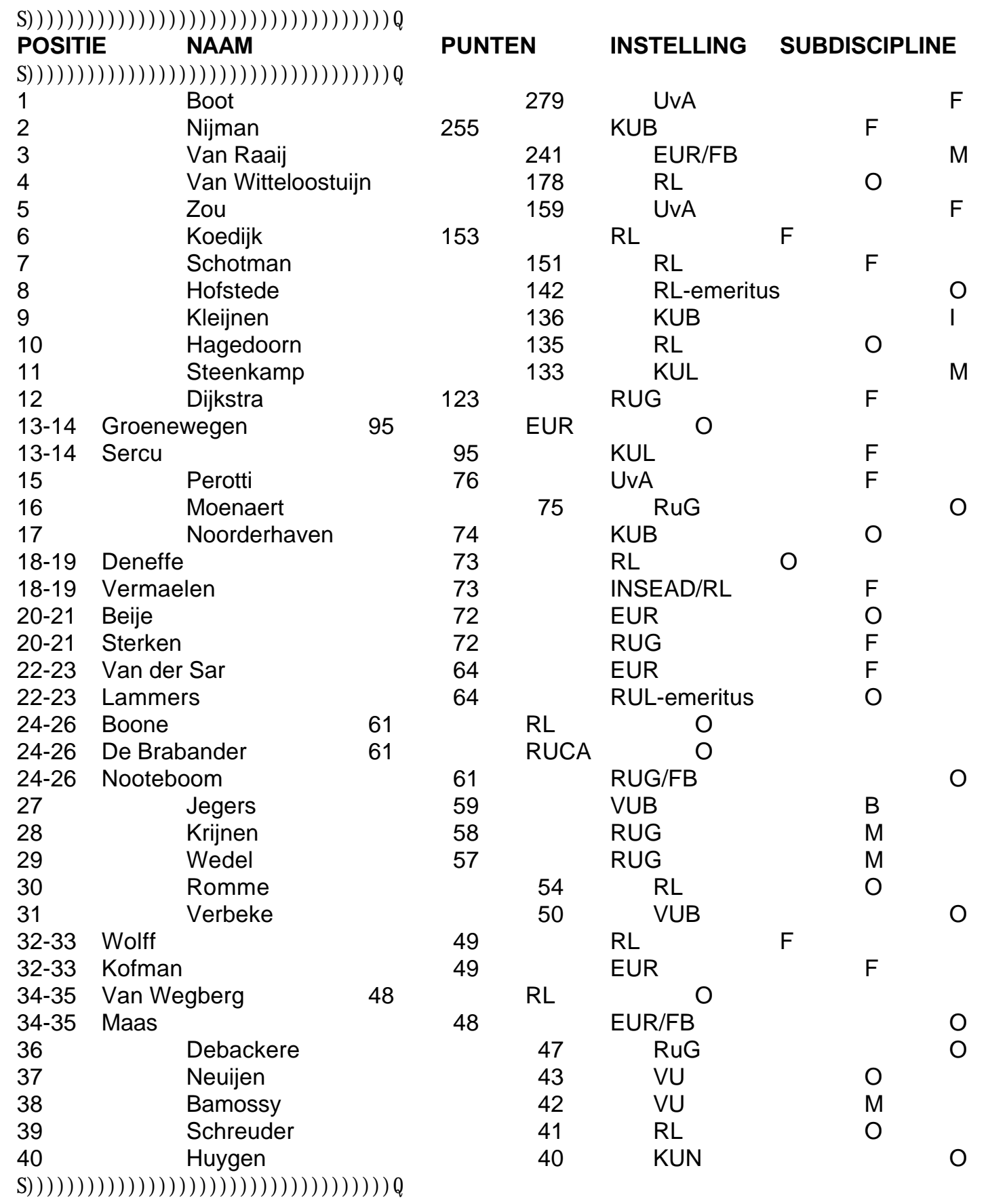


BOX 2. Publicatieprofielen

\begin{tabular}{||l|c|c||}
\hline & GENERALISTISCH & SPECIALISTISCH \\
\hline SOLISTISCH & $\mathrm{I}$ & $\mathrm{I}$ \\
\hline COÖPEREREND & $\mathrm{III}$ & $\mathrm{IV}$ \\
\hline
\end{tabular}


TABEL 15. Andere wegingen

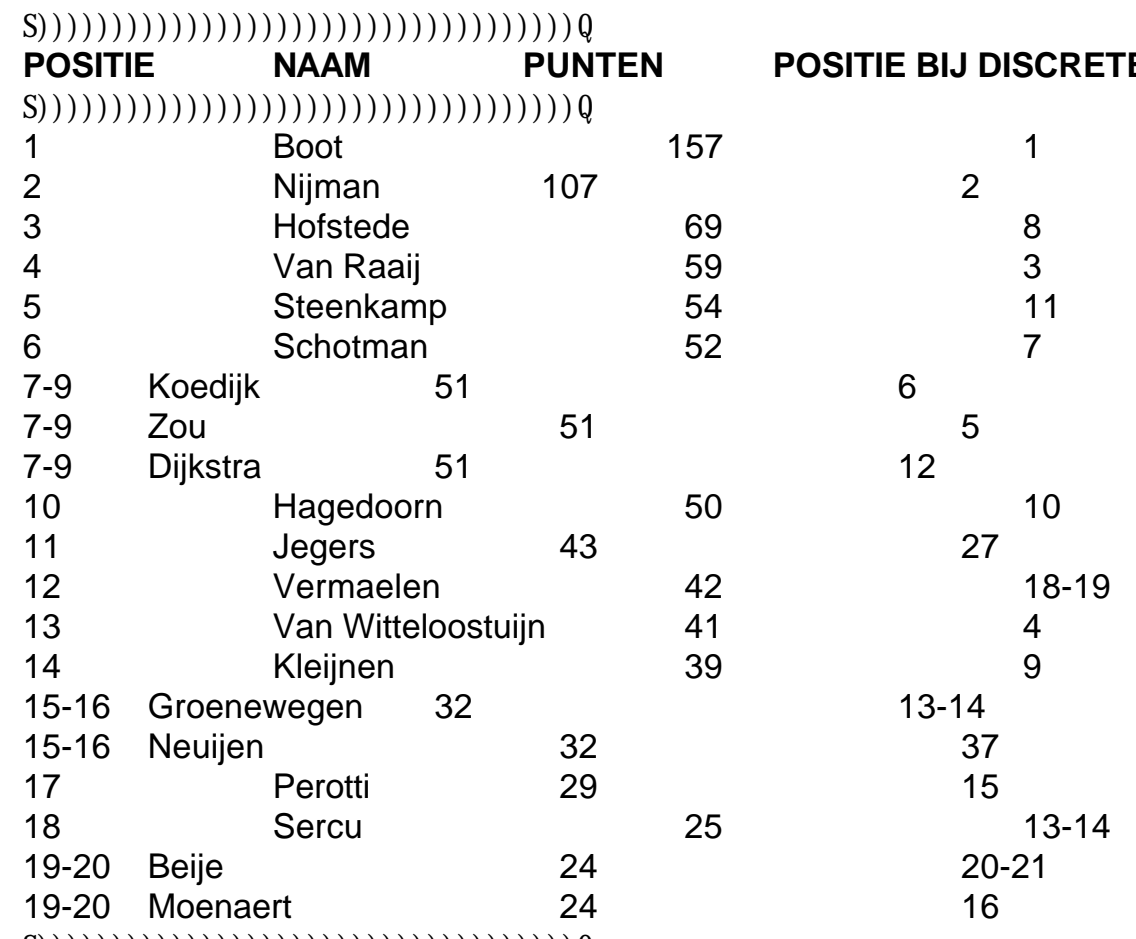




\section{TABEL 16. Generalistisch versus specialistisch}

5111111111111111111111111111111111110

\section{POSITIE NAAM}

51111111111111111111111111111111111110

1 Van Witteloostuijn

2-3 Van Raaij

2-3 Nijman

10

Boot

Zou

Steenkamp

$\begin{array}{ll}6 & \text { Steenka } \\ 7 & \text { Kleijnen }\end{array}$

8-9 Sercu

8-9 Moenaert

$10 \quad$ Koedijk

11 Sterken

12 Schotman

13-14 Hofstede

13-14 Hagedoorn

$15 \quad$ Noorderhaven

16 Dijkstra

17 Groenewegen

18-19 Debackere

18-19 Nooteboom

20-21 Boone

20-21 De Brabander

22 Wedel

23 Perotti

$24 \quad$ Huygen

25 Van Hulle

26 Maas

$27 \quad$ Elfring

28-29 Deneffe

28-29 Beije

30 Vermaelen

31 De Pelsmacker

32-34 Van der Sar

32-34 Lammers

32-34 Thio

35-36 Verbeke

35-36 Wolff

$37 \quad$ Koopman

$38 \quad$ Schreuder

39-40 Romme

39-40 Thierry

5111111111111111111111111111111111110
AANTAL

Artikelen Tijdschriften

6

6

5

5

$\begin{array}{ll}7 & 4 \\ 3 & 2 \\ 5 & 4 \\ 6 & 3\end{array}$

3

6

6

3

4

5

2

4

3

2

3

1

3

3

4

4

4

3

2

2

3

1
2

2

2

2

2

2
1

1

3

3

1

1

2

1

2

2 


\section{TABEL 17. Solistisch versus coöpererend}

511111111111111111111111111111111110

\section{POSITIE NAAM}

B

S111111111111111111111111111111111110

$2 \quad$ Boot (4) 179

$3 \quad$ Van Witteloostuijn (1)

Van Raaij (2-3)

Moenaert (8-9)

Koedijk (10)

Zou (5)

Steenkamp (6)

Sterken (11)

Schotman (12)

Kleijnen (7)

Hofstede (13-14) 93

De Brabander (20-21)

Boone (20-21)

Sercu (8-9)

Debackere (18-19) 80

Wedel (22)

Groenewegen (17) 77

Hagedoorn (13-14) 76

Van Hulle (25)

190

143

138

135

121

115

111

104

04

101

88

86
86
80
77
76

S)111111111111111111111111111111111110
POSITIE NAAM

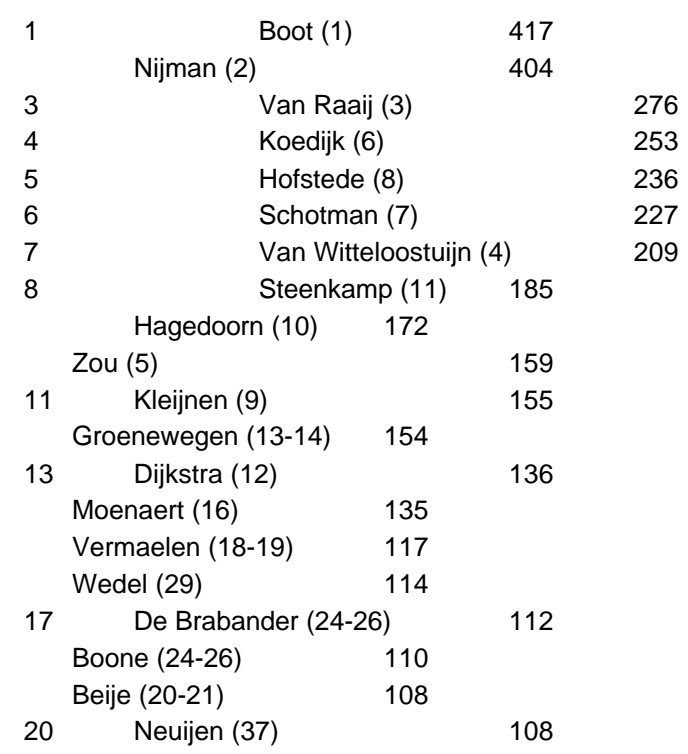




\section{BOX 3. (Sub)disciplinaire verschillen}

5111111111111111111111111111111111111111111111111111111111

DISCIPLINES

$$
\text { 5111111111111110 S S111111111111111111111111111111110 }
$$

Economie Psychologie Sociologie Toegepaste Berichtgeving Financiering Marketing Organisatie

\section{SUBDISCIPLINES}

psychologie

5111111111111111111111111111111111111111111111111111111111

Top-3

\begin{tabular}{|c|c|c|c|c|c|c|c|c|}
\hline '91 & 3,6 & 5,3 & 2,3 & 1,8 & 0,9 & 1,7 & 2,0 & 2,8 \\
\hline '93 & 3,8 & 5,7 & 2,0 & 2,3 & 1,1 & 2,2 & 1,9 & 3,7 \\
\hline$\% \quad 5,6$ & & 7,5 & 13,0 & 27,8 & 22,2 & 29,4 & 5,0 & 32,1 \\
\hline
\end{tabular}

Top-10

\begin{tabular}{|c|c|c|c|c|c|c|c|c|}
\hline '91 & 2,4 & 3,5 & 1,7 & 1,2 & 0,5 & 0,9 & 0,9 & 1,6 \\
\hline 93 & 2,5 & 3,6 & 1,5 & 1,5 & 0,5 & 1,2 & 1,0 & 2,1 \\
\hline$\% \quad 4,2$ & & 2,9 & 11,8 & 25,0 & 0,0 & 33,3 & 11,1 & 31,3 \\
\hline
\end{tabular}

5111111111111111111111111111111111111111111111111111111111

De gemiddelde 'impact score' (afgerond) van de beste drie (top-3) en tien (top-10) tijdschriften per (sub)discipline staan vermeld voor de jaren 1991 en 1993, inclusief de procentuele daling of stijging ten op zichte van het basisjaar 1991 (eveneens afgerond). 


\section{TABEL 18. Zes hitlijsten vergeleken}

51111111111111111111111111111111111110

NAAM INSTELLING

S1111111111111111111111111111111111110

Bemelmans

Leeflang

Heemstra

Kleijnen

Dorsman

Van Witteloostuijn

Bouma

Theeuwes

De Jong

Wortmann

Wijngaard

Piëst

Van der Hart

Nooteboom

Ritsema

Huizingh

Van der Vooren

Van der Tas

Biemans

Krens

Tempelaar

Geraerds

Keuning

Kamann

Algera

Van Gils

Bindenga

Spronk

Wolff

Hofstede

Klaassen

Moerland

Bamossy

Douma

Zwart RUG

Magala

Dijksma

Boone

Haan

Blokdijk

Ranglijst I

RUG/FB

RUG/FB
TUE

UvA-emeritus
TUE

TUE

KUB

VU

RUG

TUE

RUG/FB 15

RUG

VU

EUR/FB

RUG

EUR

TUE

RUG

VU

RUG

TUE

$\mathrm{RUG} / \mathrm{FB}$

EUR

EUR

RL-emeritus

VU

KUB

VU

KUB

RUG/FB

KUN

VU

KUB

$\mathrm{VU}$

UE

1111111111111111111110

\section{PLAATS OP RANGLIJST}

$\begin{array}{llllll}\text { I II } & \text { III } & \text { IV } & \text { V } & \text { VI }\end{array}$

III

$\begin{array}{llllll}\text { I II } & \text { III } & \text { IV } & \text { V } & \text { VI }\end{array}$

1

48

$6-$

$7-$

$\begin{array}{ll}2 & 1 \\ 8 & -\end{array}$

8

10

14 -

10 -

$17 \quad-\quad-$

$14 \quad 15$

$\begin{array}{llll} & 18-19 \quad 24-26 \quad 34\end{array}$

18

32

- -

$16 \quad 77$

$22-$

22

$23-$

(2)

$24-$

$20 \quad 54$

3479

$\begin{array}{lll}25 & 43 & 53\end{array}$

$\begin{array}{llll}5 & 35-36 & 32-33 & 24\end{array}$

13 13-14 8 -

31

3544

$33 \quad 72$

$\begin{array}{rrrr}40 & 33 & 72 & 57\end{array}$

3982
$-$

$-$

38

$-$

$=\quad$ 'Nationale' lijst Van Heerde \& Leeflang (1995)

II = Standaardlijst Van Heerde \& Leeflang (1995)

III = = 'Internationale' lijst Van Heerde \& Leeflang (1995)

IV $\quad=\quad$ 'Ongewogen' lijst

$\mathrm{V} \quad=\quad$ 'Gewogen' lijst

VI $\quad=\quad$ Intermediair-lijst 